San Jose State University

SJSU ScholarWorks

Master's Theses

Master's Theses and Graduate Research

2007

\title{
Consumer behavior and willingness to pay for orgnaic [i.e. organic] products
}

Pete (Chun-pei) Wang

San Jose State University

Follow this and additional works at: https://scholarworks.sjsu.edu/etd_theses

\section{Recommended Citation}

Wang, Pete (Chun-pei), "Consumer behavior and willingness to pay for orgnaic [i.e. organic] products" (2007). Master's Theses. 3410.

DOI: https://doi.org/10.31979/etd.t7gm-bjvf

https://scholarworks.sjsu.edu/etd_theses/3410

This Thesis is brought to you for free and open access by the Master's Theses and Graduate Research at SJSU ScholarWorks. It has been accepted for inclusion in Master's Theses by an authorized administrator of SJSU ScholarWorks. For more information, please contact scholarworks@sjsu.edu. 
CONSUMER BEHAVIOR AND WILLINGNESS TO PAY FOR ORGNAIC PRODUCTS

\author{
A Thesis \\ Presented to \\ The Faculty of the Department of Environmental Studies \\ San Jose State University
}

In Partial Fulfillment

of the Requirements for the Degree

Master of Science

by

Pete (Chun-pei) Wang

August 2007 
UMI Number: 1448897

\author{
Copyright 2007 by \\ Wang, Pete (Chun-pei)
}

All rights reserved.

\title{
INFORMATION TO USERS
}

The quality of this reproduction is dependent upon the quality of the copy submitted. Broken or indistinct print, colored or poor quality illustrations and photographs, print bleed-through, substandard margins, and improper alignment can adversely affect reproduction.

In the unlikely event that the author did not send a complete manuscript and there are missing pages, these will be noted. Also, if unauthorized copyright material had to be removed, a note will indicate the deletion.

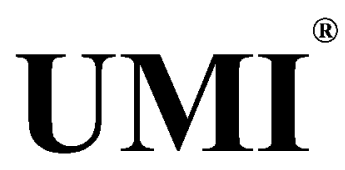

UMI Microform 1448897

Copyright 2007 by ProQuest Information and Learning Company.

All rights reserved. This microform edition is protected against unauthorized copying under Title 17, United States Code.

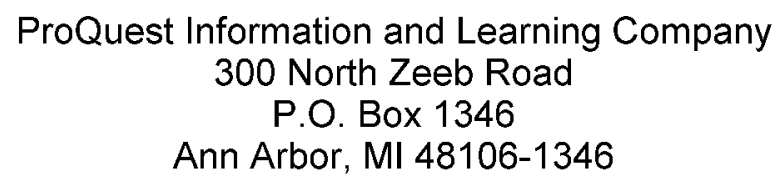


(C) 2007

Pete Wang

ALL RIGHTS RESERVED 
APPROVED FOR THE DEPARTMENT OF ENVIRONMENTAL STUDIES

Katar cushing

Dr. Katherine Cushing, Associate Professor, Department of Environmental Studies, San Jose State University

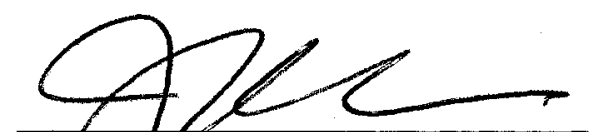

Dr.Jandes D. Lee, Assistant Professor, Department of Sociology, San State University

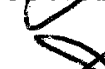

Professor Jon E. Ragatz, The Green MBA Program, Dominican University of California

APPROVED FOR THE UNIVERSITY

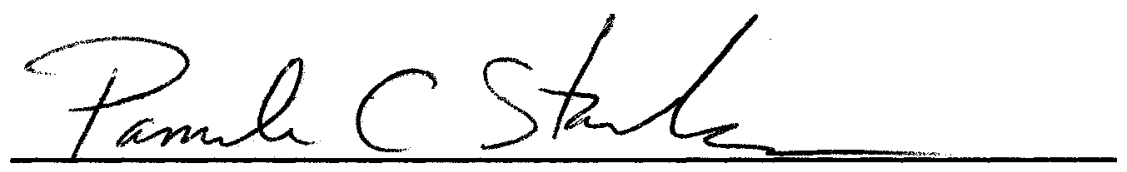




\title{
ABSTRACT \\ CONSUMER BEHAVIOR AND WILLINGNESS TO PAY FOR ORGNAIC PRODUCTS
}

\author{
by Pete (Chun-pei) Wang
}

Today, an increasing number of consumers choose to purchase organic food to show their concern and support for products that benefit both people and the environment. Most consumers, however, know little about organic cotton, given the fact that conventional cotton farming is considered one of the most polluting farming practices in agribusiness. The results of my study indicate consumers' behavior of buying organic food is directly influenced by their knowledge of organic farming practices, environmental attitudes, and sociodemographic characteristics. On the other hand, consumers' behavior of buying organic cotton clothing is directly influenced by their environmental attitudes, and the frequency of organic food purchase. Knowledge of conventional farming also play a critical determinant in transforming organic food buyers into organic cotton buyers. Moreover, consumers are most concerned about organic cotton clothing's high premium price, poor product variety, lack of distribution points and lack of product information. 


\section{ACKNOWLEDGEMENTS}

This research project could not be finished without the help of many people. First, I want to specially thank my committee members, Dr. Katherine Cushing, Dr. James Lee, and Professor Jon Ragatz, who showed their unconditional support to me and are always dedicated to their profession. I would also like to thank the following individuals participating in this study and provided valuable comments: Rachel Pearson from speesees, Lynda Grose from Sustainable Cotton Project, Terry Young from Organic Exchange, Kevin Myette from REI, and Selma Comodo from the Rainbow Grocery. Finally, I want to thank the organizations I have closely worked with in the past few years, whose hard work has not only expended my knowledge on organic products, but also made this world cleaner and safer for our future generations: California Certified Organic Farmers (CCOF), Organic Exchange, Pesticide Action Network (PAN), speesees, and Sustainable Business Institute. 


\section{TABLE OF CONTENTS}

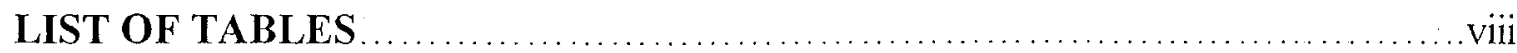

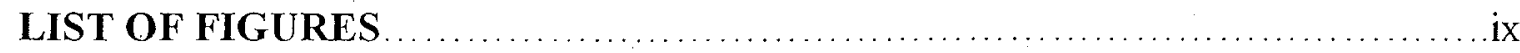

Introduction................................................................. 1

Environmental and Social Impacts of Conventional Cotton Farming ................. 1

Organic Cotton: An Alternative Choice ....................................... 3

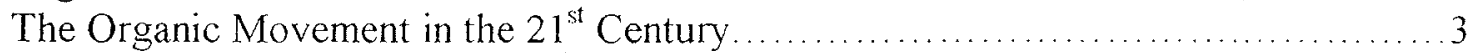

Problem Statement..............................................................

Related Reseaerch...................................................................8

Consumer Attitude, Knowledge, and Willingness to Pay for Organic Food ............ 8

Environmentally-Conscious Behavior Models and Mechanism.......................9

Theory of Reasoned Action (TRA) .............................................. 9

Internal and External Factors................................................ 9

Market Segmentation- Socioeconomics, Pyschographics and Behavioristics............. 11

Research Objectives......................................................... 13

Research Questions.............................................................14

Methods..............................................................................15

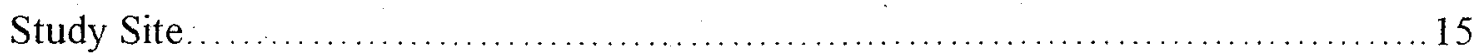

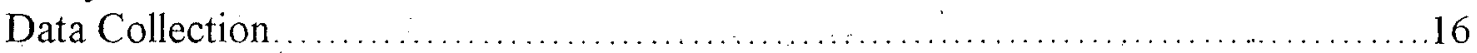

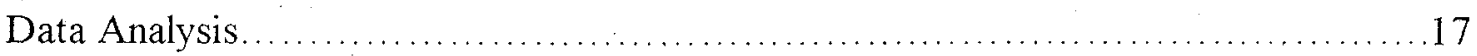

Quantitative Questions Coding ......................................... 17

Descriptive Statistics.......................................................... 18

Market Segmentation....................................................... 18

Causality of Consumer Buying Organic Food and Organic Cotton Products ......... 19

Results......................................................................20

Descriptive Statistics ................................................. 20

Socioeconomic Characteristics.............................................. 20

Attitude and Knowledge .................................................... 20

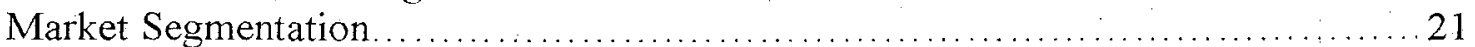

Characteristics of Market Segments........................................... 21

Motivations for Buying Organic Cotton Clothing ............................. 23

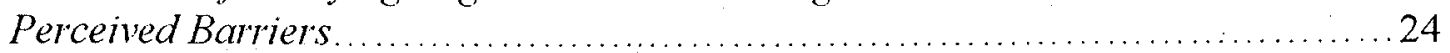

Behavioral Analysis of Organic Food Purchasing .................................. 25

Internal Factors Affecting Organic Food Purchase.............................. 25 
Behavioral Analysis of Organic Cotton Clothing Purchasing ...................... 28

Internal Factors Affecting WTP ............................................. 28

Internal Factors Affecting Organic Cotton Clothing Purchase Decision............ 31

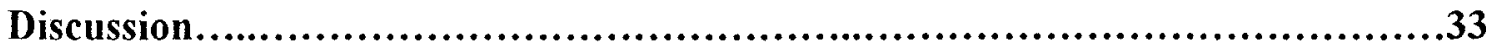

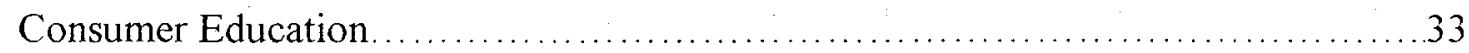

Educating Consumers to Think Beyond Price Tags............................ 33

Using Eco-labeling and Product Labels.................................... 34

Education Taken Place in Retail Stores......................................... 35

Demarketing of Conventional Cotton Products ............................... 36

Reducing Product Prices......................................................... 37

Considering Using Other Sustainable Cotton ................................. 38

Reducing Subsidies on Conventional Cotton Fields............................... 39

Reducing Distribution Costs ................................................. 40

Conclusion....................................................................... 42

Internal Factors Affecting Consumer Purchase Behavior ......................... 42

Market Segmentation ....................................................... 44

The Path from Brown to Light Green..................................... 45

The Path from Light Green to Dark Green................................... 48

Product Positioning .............................................................. 49

References.................................................................52

Appendices......................................................................59

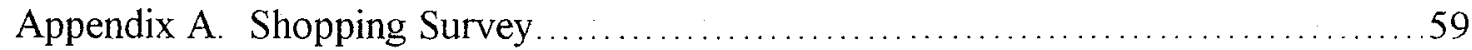

Appendix B. Survey Coding................................................... 64 


\section{LIST OF TABLES}

Table 1. Dependent and Independent Variables of Statistical Tests. 19

Table 2. Comparative Demographics of the Study Sample and the Population of the San Francisco Bay Area. 20

Table 3. T-tests of Factors between Each Consumer Segment. 23

Table 4. Coefficients and Standard Errors of Regression of Frequency of Organic Food Purchase on Independent Variables.

Table 5. Coefficients and Standard Errors of Regression of Willingness to Pay on Independent Variables 30

Table 6. Coefficients and Standard Errors of Regression of Purchase of Organic Cotton Clothing on Independent Variables 


\section{LIST OF FIGURES}

Figure 1. Global Growth of Organic Cotton Demand ............................ 5

Figure 2. The Conceptual Framework of Factors Influencing a Consumer's Decision in

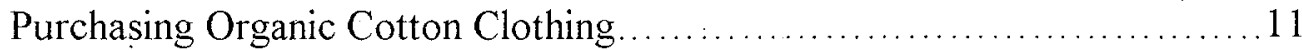

Figure 3. Consumer Motivations for Purchasing Organic Cotton Clothing ............. 24

Figure 4. Perceived Barriers Influencing Consumers' Purchasing Decisions on Organic

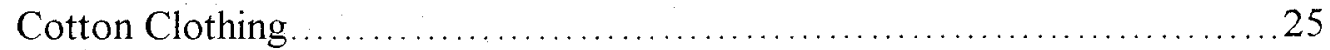

Figure 5. Path Analysis of Causal Relationships between Internal Variables............ 44

Figure 6. Factors Influencing Consumer Purchase Behavior on Organic Food and

Organic Cotton Clothing ........................................48 


\section{Introduction}

Emvironmental and Social Impacts of Comentional Cotton Farming

For centuries, cotton has served as one of the most popular natural commodities to humankind. Nowadays, cotton fields cover over 70 million acres of land on the earth's surface, and cotton is widely processed to produce cottonseed for livestock feed, cotton oil for food processing and, of course, fabric for clothing (The Fabric of Their Lies: Cotton's Devastating Legacy, 2002). The United States, the world's largest cotton producing country, provides over $20 \%$ of the global cotton supply, and the U.S cotton industry alone generates over $\$ 6$ billion of annual revenue. In fact, since 1996 , each American has consumed more than 75 pounds of cotton per year (ERS/ USDA, 1996; ERS/ USDA, 2006). On a global scale, the demand for cotton continues to rise in developing economies, such as China and India, which consume $37 \%$ and $15 \%$, respectively, of the world's cotton supply (Greene, 2003)

While cotton has provided people worldwide with comfort and convenience, modern cotton farming is perhaps the most environmentally devastating industry in agricultural history. While cotton is grown on only $2.4 \%$ of the world's farmland, conventional cotton farming uses $25 \%$ of the world's insecticide and more than $10 \%$ of its pesticides. The purchase of these toxic chemicals costs U.S. taxpayers a total of $\$ 2.6$ billion every (Ingram, 2002; PANNA, 1998). On average, every t-shirt made with conventional cotton requires $1 / 3$ pound of synthetic pesticides and insecticide to produce (The Fabric of Their Lies: Cotton's Devastating Legacy, 2002). In some developing countries, it is estimated that roughly $50 \%$ of all pesticides are applied in cotton 
cultivation, and these pesticides have killed at least 20,000 people every year (PANUK, 2005)

In 2005 , the conventional cotton industry received $\$ 3.3$ billion in farm subsidies from the U.S. government, making it the third largest farm subsidy recipient in the United States, after corn and wheat. Between 1995 and 2005, 81\% of such cotton subsidies went to only $10 \%$ of the cotton growers, who were mainly corporate-owned and grew cotton using monocultural and chemical-intensive farming practices (Environmental Working Group, 2004). In California, 12 to 13 million pounds of pesticides are deposited onto cotton fields every year, amounting to 14 pounds of pesticides per acre.

The U.S. EPA has identified half of the most commonly used pesticides on cotton fields as carcinogenic (California Department of Pesticide Regulation, 2002; The Fabric of Their Lies: Cotton's Devastating Legacy, 2002). A 2002 report from the U.S. Center for Disease Control and Prevention states that every study participant contained approximately 13 types of pesticides in their bodies, and two of them have levels above the government safety threshold. Pesticides can enter the human body through contaminated water, soil, crops, and atmospheric transport. They can affect the health of children by contaminating breast milk, and they increase the risk of developing leukemia by nearly seven-fold (Jensen, Mazhitova and Zetterstrom, 1997; Lotus, 2004).

Conventional cotton farming also poses a great threat to local biodiversity. $83 \%$ of conventional cottonseeds grown in the United States are now genetically modified. Many scientists hold that genetically modified crops may contaminate native plant species, eliminate natural pollinators, and eventually modify the structure and integrity of 
the local ecosystem (ERS/USDA, 2006). As a result, not only does chemical-intensive cotton farming pose significant health risks to all human beings, it also endangers the earth's fragile ecosystem.

Organic Cotton: An Alternative Choice

In contrast to conventional, chemical-intensive cotton farming, organically grown cotton represents an environmentally and socially responsible alternative. Because growing organically means that no toxic, synthetic fertilizers and pesticides can be used, organic farming maintains soil fertility and nutrients, and sustains the local ecosystem. Certified organic cotton fabric requires the implementation of environmentally friendly practices during the processing and manufacturing stages. These practices include the banning of the use of carcinogenic substances such as formaldehyde, heavy metals, and chlorine bleach, as well as the mandatory recycling or pre-treating of toxic discharges before they are released to the water source (Ferrigno, 2005; Sanfilippo, 2007). In addition, organic certification is the only standard that guarantees that the product does not contain any genetically modified crops and ingredients. Organic cotton therefore helps preserve local habitat and biodiversity (Coody, Riddle and Rosen, 2003; Greene, 2003).

The Organic Movement in the $21^{\text {st }}$ Century

Many researchers believe the United States is currently experiencing a new wave in organic movements. Browne et al. (2000) describe this change as "a unique grassroots, consumer-driven economy that reflects consumers' concerns about the polluted environment, about their desires for food safety, and about environmental and social 
justice." Consumers have begun to realize that the extra price premium they are paying for an organic product not only buys them a healthier and safer product to consume but also, more importantly, buys their children a cleaner environment to sustain. Consumer interest in supporting organic farming has tremendously stimulated the annual retail sales of organic food in the United States. The annual sales growth has reached 20\%, and has generated more than $\$ 3.5$ billion every year since 1996 (Dimitri and Greene, 2002).

As for organic cotton, after experiencing a near 60\% drop in domestic production between 1995 and 1998 due to low market responses, it has finally regained consumer attention in the new millennium (The Organic Cotton War, 1997). Annual U.S. organic cotton production increased steadily to over $15 \%$ between 2003 and 2005 , while the annual sales of organic cotton products is expected to grow by $15.5 \%$ between 2004 and 2008 (Myers and Stolton, 1999; OTA, 2006). Not only has organic cotton clothing become the prominent product line of some major clothing manufacturers such as Patagonia and Levi's, the number of small-scale retailers and brands selling it grew from a few hundred to more than 1,200 by the end of 2005 (Organic Cotton Market Report, 2006). As Figure 1 indicates, global production, retail sales, and manufacturers' demands for organic cotton have all been significantly increasing in the past few years. Although organic cotton still represents only about $0.06 \%$ of current global cotton production, it certainly has the potential to enjoy a similar success to that of organic foods in the near future (Burden, 2004). 


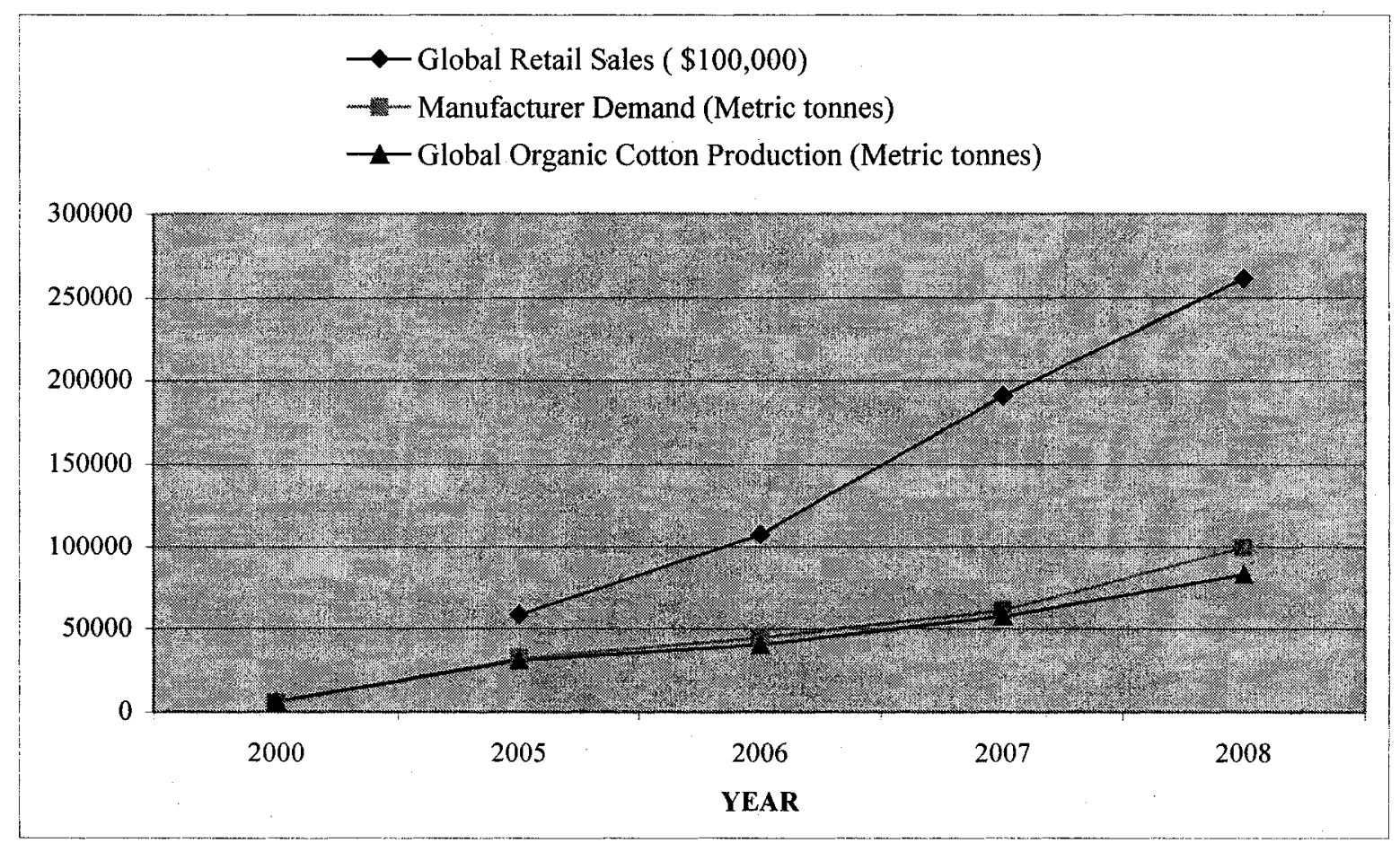

Note. From "Organic Cotton Market Report 2006," by Organic Exchange

Figure 1. Global Growth of Organic Cotton Demand 


\section{Problem Statement}

From the marketing perspective, the market for organic food has entered the "growth" stage, in which the majority of buyers have a basic understanding of the product's features and benefits, and the market has established a stable growth in sales while more companies continue to introduce new products. In contrast, the organic cotton sector is still at its "introduction" stage, in which sales grow slowly, and the major objective for suppliers in this stage is to create consumer awareness, to educate the consumer about product benefits, and to stimulate product trial (Kerin, Hartley and Rudelius, 2004). With organic food, most buyers are already familiar with their direct health benefits such as "chemical-free" and "more nutritious" (Rabb and Grobe, 2005). In contrast, the majority of consumers might not consider organic cotton products as equally valuable because these products do not often deliver obvious and direct health benefits to users. Consumers are likely to buy a product only if they perceive some added value in that product. It is unlikely that they would buy an organic cotton product solely because of its environmentally friendly features. The major task of organic cotton marketers is therefore to understand the target market of organic cotton products, to educate them to think beyond their own self-interest and the product's direct benefits, and finally to convince consumers to take into account the hidden social and environmental costs of producing conventional cotton apparel into their decision-making processes (Golding and Peattie, 2005).

In contrast to the numerous studies that have been conducted on organic food, only a handful of marketing research has been specifically focused on organic cotton 
products. Companies considering selling organic cotton products will be unable to design and execute a successful marketing plan unless they first understand who their consumers are, how consumers evaluate these products, and what barriers consumers experience to buying organic cotton products. Without first addressing these issues, organic cotton apparel sales will continue to lag well behind organic food in the general marketplace. 


\section{Related Research}

Consumer Attitude, Knowledge, and Willingness to Pay for Organic Food

Specific studies on organic food purchases show a positive relationship between buyers' awareness, attitude, and knowledge, and their willingness to pay (WTP) for organic food. William and Hammitt (2000) point out that not only do organic food buyers tend to be more ecologically conscious, they are also more likely than non-buyers to engage in health-promoting and environmentally supportive behavior. Frequent organic food buyers also often show a stronger concern for issues related to food safety such as chemical overuse in agriculture, and pesticide residue on produces - as well as a stronger belief and confidence in certified organic products, and a better knowledge about organic farming practices than do less frequent buyers (Blake and others, 2003; Cranfield and Magnusson, 2003; Gil, Gracia and Sanchez, 2000; Raab and Grobe, 2005; Soler and Gil, 2004; Williams and Hammitt, 2000). Moreover, consumers with stronger positive attitudes towards organic food perceive higher values in organic food and believe organic food should be more expensive. They also tend to be less price-sensitive and willing to pay an extra 5\% - 30\% for different organic products (Bang and others, 2000; Blake and others, 2003; Gil, Gracia and Sanchez, 2000; Krystallis and Chryssohoidis, 2005; Soler and Gil, 2004; Tanner and Kast, 2003). However, some studies indicate that although organic food buyers show a high level of concern for the environment, they primarily choose to buy and consume organic food because they believe it is safer and has greater health benefits than conventional food. Its environmental benefits seem less important to them (Cranfield and Magnusson, 2003; Gil, Gracia and Sanchez, 2000). 
Environmentally-Conscious Behavior Models and Mechanism

Theory of Reasoned Action (TRA). Two behavioral models are commonly adapted by researchers to explain the mechanism behind people's environmentally conscious behavior. Fishbein and Ajzen's theory of reasoned action (1975) states that people only perform the behavior that they believe will create the more desirable outcome to other alternatives (Fishbein and Ajzen, 1975). Bang et al. (2000) later simplify the TRA model and describe the formation of humans' environmentally conscious behavior as a linear relationship: knowledge-belief-attitude-behavior. This model posits that knowledge constructs one's belief, belief develops one's attitude, and attitude eventually motivates one's behavior. According to this model, an individual's attitude toward the environment has a greater impact on his/her motivation to perform an environmentally- conscious behavior than do knowledge and belief. The TRA model has been supported by studies on various environmentally-conscious behaviors (McCarty and Shrum, 1994; Bang and others, 2000; Laroche, Bergeron and Barbaro-Forleo, 2001).

Internal and External Factors. The survey study from Gardyn (2003) reports that although $80 \%$ of Americans state that their major reason for considering recycled paper products is the environmental benefit they offer, only $57 \%$ admitted to actually buying them. Similarly, other studies have found that when people make decisions in a market where they have freedom to access multiple choices, their behavior is always more complicated than the TRA describes. Tanner and Kast (2000) and Laroche,_Bergeron and Barbaro-Forleo (2001) describe a consumer's purchase behavior as the artifact of both internal /personal variables (i.e. attitude, knowledge, past experience) and external/ 
contextual variables (i.e. product price and quality, and convenience), and no single variable has a pre-dominant effect on making their final decisions. In other words, an individual's environmentally conscious behavior is the reflection of his/her lifestyle, and is influenced by both an individual's personal factors, and external factors they are currently coming across.

A person's lifestyle, as defined by Lorek and Lucas (2003) defines, is a distinctive mode of living and pattern of actions that includes their "actual purchase experience... and their sensitivity to different external factors." The interactions between internal and external factors would help to explain why high concern over the environment was always found among the general public, but behaviors consistent with such concern were often lacking (Gardyn, 2003; Lohr and Semali, 2000; Ottman, 1994). Using the purchase of organic food as an example, Figure 2 highlights the possible personal and contextual factors consumers might face when making food-buying decisions. Major external factors with regard to purchasing organic food include premium price, inconvenient store locations, unclear product information, weak branding, and poor quality; consumers will not make long-term commitments to organic products until these external factors are well addressed by suppliers (Bergeron and Barbaro-Forleo, 2001; Gardyn, 2003; Hamm, 1995; Hill and Lynchehaun, 2000; Lohr, 2001; Lohr and Semali, 2000; Ottman, 1994; Tanner and Kast, 2003). 


\section{Exteinal Factors}

\section{Internal Factors}

1. Sociodemographics

2. Knowledge and Attitude (TRA)

3. Behavioral Pattern

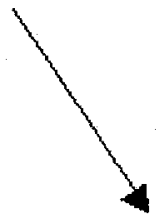

1. Product Prices

2. Poor Product Quality

3. Poor Variety

4. Inconvenient Store Locations

\section{Buying Organic Food}

Figure 2. The Conceptual Framework of Factors Influencing a Consumer's Decision in

Purchasing Organic Cotton Clothing (Source: Tanner and Kast, 2000; Laroche, Bergeron and Barbaro-Forleo, 2001).

\section{Market Segmentation - Socioeconomics, Psychographics and Behavioristics}

Market segmentation is the first step taken prior to developing marketing plans.

In this process, marketers first identify the potential customers and group them based on their shared characteristics. Once people are grouped, each group becomes a potential target market segment, and it allows marketers to develop marketing strategies that specifically fit the characteristics of each market segment. Marketers typically group their target customers according to their demographics, psychographics, or behavioristic characteristics (Arens, 2004). Studies on consumers' socioeconomic backgrounds - such as age, income level, and education level - show that they do not always have a consistently significant effect on people's environmentally conscious behavior (ECB) 
(Chan, 1999; Gil, Gracias and Sanchez, 2000; Guagnano, 2001; Jan, Fu and Huang, 2005; Laroche, Bergeron, and Barbaro- Forleo, 2001; Roberts, 1996). In contrast, both psychographic characteristics - including personal values, attitude and knowledge - and behavioristic patterns are considered the more effective indicators of people's environmentally conscious behavior. Previous studies found that green consumers are often supportive of green products, are more familiar with the environmental issues related to the products they purchase, and are more likely to participate in recycling and belong to environmental organizations than are consumers in other segments (Cranfield and Magnusson, 2003; Hunter and Rinner, 2004; Jan, Fu, Huang, 2005; Laroche, Bergeron and Barbaro- Forleo, 2001; McCarthy and Shrum, 1994; Tanner and Kast, 2003; Tracy and Oskamp, 1983; William and Hammitt, 2000). 


\section{Research Objectives}

The objective of this exploratory marketing research is to identify the buyers of organic cotton clothing, to understand their perceptions of the clothing, and to further analyze their decision-making processes and purchase behavior of buying organic food and buying organic cotton clothing. First, I examine whether or not consumers' willingness to pay for organic cotton clothing (WTP) is significantly correlated with their socioeconomic background, psychographic attributes (knowledge and environmental attitude levels), and their behavioristic patterns (purchasing frequency of organic food). Second, I group the study sample into different segments based on their purchase behavior, and addresses the barriers consumers in each segment perceive when purchasing organic cotton products. Finally, this study discusses how marketers could better design their marketing plans based on the survey results. 


\section{Research Questions}

This study is to exam if any significant relationship exists between consumers' willingness to pay for organic cotton clothing (WTP), environmental attitudes, knowledge about organic farming practices, and the purchasing frequency of organic foods. Specifically, this study will address the following research questions:

1. Is consumer stated WTP a valid indicator of their actual purchase behavior?

2. Are organic food buyers more likely to support organic cotton clothing than nonorganic food buyers?

3. Are consumers' environmental attitudes and knowledge about organic farming practices statistically associated with their willingness to pay for organic cotton clothing?

4. What are the consumer perceptions of organic cotton clothing?

5. How can the marketing community understand their target market and increase consumer demand for organic cotton clothing through market research and segmentation? 


\section{Methods}

Research data were collected at the following locations in San Francisco, CA- the Trader Joe's between $9^{\text {th }}$ Street and Bryant Street, the Rainbow Co-op Grocery on 1745 Folsom Street, and the Safeway supermarket on $16^{\text {th }}$ Street.

Study Site

The San Francisco Bay Area of Northern California is well- known for its diverse population, cultures and rich history of environmental and social movements. The Bay Area residents have a higher percentage of college graduates than the national average ( $40 \%$ vs. $26 \%$ ), and $30 \%$ higher per capita income than the national average ( $\$ 34,079$ vs. $\$ 24,020$ ) (Bay Area Census, 2005; U.S. Census, 2000). Residents in the Bay Area today can purchase a wide variety of organic products from numerous purchase points including national chain supermarkets, local grocery stores, and regional farmer's markets. In general, consumers in the San Francisco Bay Area are likely to be adequately informed about current environmental issues and have a basic understanding in organic farming practices and its benefits than those in other major cities.

Even though consumers could find similar food items from all three participating stores, each store apparently positions itself differently in the marketplace. Safeway and Trader Joe's are both major national chain supermarkets in North America, and sell both conventional grocery goods and organic products. Safeway is the third largest conventional supermarket chain in the U.S that recently introduced its new private organic label- "O Organic" (Haberkorn, 2006). Although today Safeway sells more than 150 different organic products, low-priced conventional food are still the major product 
type sold in Safeway. Safeway is positioned to provide its customers highly recognized brands, convenient store locations and hours, relatively low product prices, and a large product variety. In contrast, the Rainbow Grocery is an independent grocery store owned and operated by its members. The majority of food sold at the Rainbow Grocery includes locally-grown, natural and organic products, and it tends to specifically target green consumers, who are more concerned about a product's added values, such as the environmental benefits in organic products, and the social justice in fair trade goods. Finally, Trader Joe's is likely to be positioned between the corporate-owned Safeway and independent Rainbow Grocery. Trader Joe's operates in only 23 states, selling more variety of natural and organic products than Safeway, but fewer than Rainbow Grocery. The distinctive characteristics of target customers among three study sites provides this research a solid ground to distinguish the differences between consumer attitude toward the environment, knowledge, frequency of organic foods purchase, and WTP for organic cotton clothing across the study sites.

\section{Data Collection}

Self-administrated questionnaires were distributed to adult shoppers using the convenience sampling method. At each study site, a table was set up near the entrances of the stores facilitating communication with shoppers. 150 surveys were collected at each study site between June and September 2006, and total of 450 surveys were completed.

The questionnaire, attached in Appendix 1, included a cover page describing study objectives, respondent's rights and confidentiality, and brief survey instructions. 
The body of the questionnaire consisted of four sections: (1) Knowledge- six True/ False questions regarding consumer knowledge about conventional farming's environmental impacts, about the certification standards of organic products, and about organic cotton production and certification; (2) Attitude- six questions testing consumers' attitude toward the general environmental issues, toward supporting environmentally-friendly products, and toward organic foods; (3) Behavior- six questions addressing consumer purchase behavior and experience on buying organic foods and organic products, and (4) Sociodemograhics- survey participant's demographic information, including gender, age, education level, income level, and ethnic background.

\section{Data Analysis}

Quantitative Questions Coding. In the Knowledge Section, one point was awarded for each correct answer while no point was awarded for wrong answers, and the sum represented each respondent's knowledge score. In the Attitude section, respondents' attitudes are measured based on the Likert-type scale, whose score was ranged between +12 (highly positive) and -12 (highly negative). Most questions in this section are taken directly from the previous studies on similar subjects (Cranfield and Magnusson, 2003; Dunlap Van Liere, 1978; Kinnear and Taylor, 1973; Tanner and Kast, 2003). In the Behavior section, respondents were asked to provide the main reasons why they would choose to buy organic cotton clothing, and also the major conflicts they had encountered when trying to buy organic cotton clothing. Respondents who stated they were willing to pay more for an organic cotton t-shirt were then asked to select the specific percentage of price premium they were willing to pay over regular cotton T-shirt 
at the level of $10 \%, 50 \%, 100 \%, 150 \%$, and $200 \%$ or more. The complete coding scheme for each section of survey is listed on Appendix 2.

Descriptive Statistics. Descriptive statistics of the sample's sociodemographic background, attitude and knowledge levels, willingness to pay for an organic cotton $\mathrm{t}-$ shirt (WTP), and frequency of organic food purchase were generated. The sample's sociodemographic data were compared with the data recorded in the 2005 Bay Area Census to study how closely the research sample represents the population of the San Francisco Bay Area.

Market Segmentation. In this study, market segments were formed based on the respondents' purchase behavioral patterns. I classified survey respondents into three groups based on their answers to Question 3- the frequency of organic food purchase in the past three months, and Question 4- whether they had purchased organic cotton clothing in the past six months. The mean of attitude, knowledge, WTP, and frequency of organic food purchase of each group were first calculated, and t-tests were then applied using Microsoft Excel to study whether there was a significant difference on each variable between groups.

Consumers' perceptions of organic cotton clothing from each segment were recorded according to their responses on Question 4(a) asking the major reasons attracting them to purchase organic cotton clothing, and Question 4(b) asking the major reasons they chose not to purchase organic cotton clothing. Studying consumers perceptions of organic cotton clothing helps to understand consumers' motivations for buying organic cotton clothing, and also the potential barriers consumers had experienced 
and encountered when making a purchase decision of organic cotton clothing. Finally, on the basis of the study sample responses, marketing recommendations for improving the two major marketing mixes of organic cotton clothing - price and promotion - were provided in the last section of this study.

Causality of Consumer Buying Organic Food and Organic Cotton Products. Multiple regression tests were conducted to study the internal factors having significant effects on consumers' behavior of buying organic food and organic cotton clothing and on their WTP (Table 1). Consumers' behavior of buying organic food was studied through measuring the regressions between frequency of organic food purchase and internal variables, while the behavior of buying organic cotton clothing was studied through measuring the regressions between these variables and their purchase experience in the past six month.

Table 1. Dependent and Independent Variables of Statistical Tests.

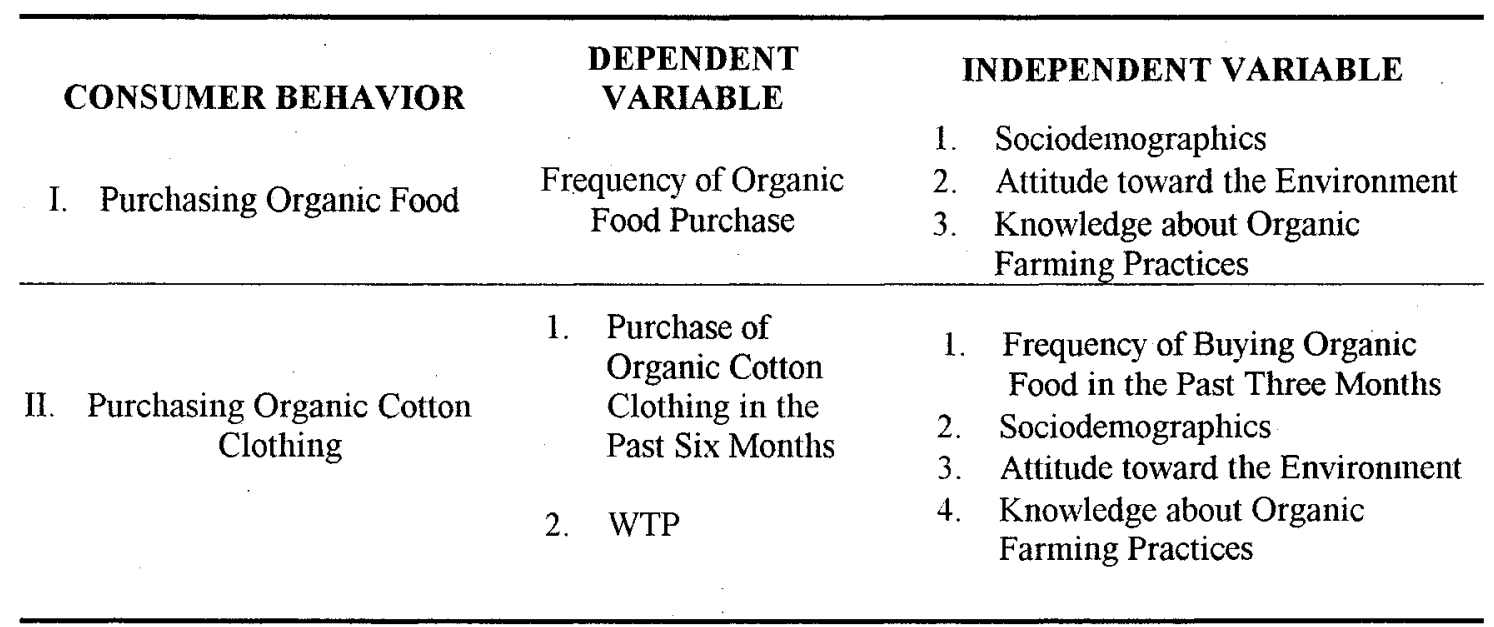




\section{Results}

\section{Descriptive Statistics}

Socioeconomic Characteristics. The descriptive analysis of the survey data revealed that the majority of the study sample was aged between $20-39$ years (52\%), was at least college graduates $(65 \%)$, and had a personal income of below $\$ 3000$ per month (65\%). Table 2 shows the comparisons between the study sample and the San Francisco Bay Area population recorded in the 2005 Census, and it suggests that the study sample was biased towards female, white, lower income levels, and higher education levels (Bay Area Census, 2005).

Table 2. Comparative Demographics of the Study Sample and the Population of the San Francisco Bay Area.

\begin{tabular}{|c|c|c|c|c|c|c|c|}
\hline \multirow[b]{2}{*}{ SOURCE } & \multicolumn{2}{|c|}{ GENDER } & \multirow{2}{*}{$\begin{array}{c}\text { INCOME } \\
\text { Monthly } \\
\text { Personal } \\
\text { Income } \\
\end{array}$} & \multirow{2}{*}{$\begin{array}{l}\text { AGE } \\
\text { Median }\end{array}$} & \multirow{2}{*}{$\begin{array}{c}\text { EDUCATION } \\
\text { College } \\
\text { Degree and } \\
\text { Above } \\
\end{array}$} & \multicolumn{2}{|c|}{ ETHNICITY } \\
\hline & Male & Female & & & & White & $\begin{array}{l}\text { Non- } \\
\text { White }\end{array}$ \\
\hline Study Sample & $42 \%$ & $58 \%$ & $\$ 2,500$ & 35 & $65 \%$ & $65 \%$ & $35 \%$ \\
\hline $\begin{array}{c}\text { San Francisco } \\
\text { Bay Area } \\
\text { Population in } \\
2005\end{array}$ & $50 \%$ & $50 \%$ & $\$ 2,912$ & 37.3 & $41 \%$ & $57 \%$ & $43 \%$ \\
\hline
\end{tabular}

Note. From "2005 American Community Survey Estimates," by U.S Census Bureau

Attitude and Knowledge. The vast majority of respondents showed positive attitudes toward the general environmental issues (85\%), toward supporting environmentally-friendly products (90\%), and toward organic food (92\%). However, 
only $39 \%$ of respondents, whose knowledge scores were above the average, showed adequate knowledge about organic farming practices, while the rest $61 \%$ of respondents were considered unknowledgeable about organic farming practices. In the specific knowledge category, $65 \%$ of respondents understood the negative impacts of conventional farming, while the majority of respondents $(80 \%)$ was unfamiliar with organic certification standards, and organic cotton production and certification processes $(67 \%)$. Results indicated that the majority of the study sample had positive environmental attitudes, but still lacked in-depth knowledge about organic farming practices.

\section{Market Segmentation}

Characteristics of Market Segments. The study sample was divided into three groups based on their answers to Question 3- the frequency of organic food purchase in the past three months, and Question 4- whether they had purchased organic cotton clothing in the past six months. These three groups are categorized as:

I. Conventional Food Buyer- respondents who have never purchased organic food and organic cotton clothing in the past three months.

II. Organic Food Buyer-respondents who have purchased organic food but not organic cotton clothing in the past three months.

III. Organic Cotton Buyer- respondents who have purchased organic cotton clothing in the past three months.

$74 \%$ of the study sample fell into the Organic Food Buyer category, followed by $22 \%$ into the Organic Cotton Buyer, while only $4 \%$ of respondents belonged to the 
Conventional Food Buyer. T-tests suggested there was no significant difference in socioeconomic characteristics across different consumer segments; however, significant differences were found in knowledge, environmental attitudes, frequency of organic food purchase, and WTP between different segments (Table 3). Table 3 shows that consumers in the Organic Cotton Buyer group had the highest frequency of organic food purchase, and highest WTP among the three groups. Respondents in the Organic Cotton Buyer group also were more knowledgeable about the impacts of conventional farming practices than respondents in other groups; however, their environmental attitude was not significantly greater than those in the Organic Food Buyer group.

On the other hand, consumers in the Organic Food Buyer group showed the intermediate levels in knowledge, environmental attitudes, buying frequency of organic food, and WTP. Organic food buyers had significantly higher positive attitude toward supporting green products and toward organic food than conventional food buyers, and they were also more knowledgeable about the impacts of conventional farming practices than conventional food buyers. Finally, the results suggested there were no significant differences in consumers' attitudes toward the general environmental issues, knowledge about organic certification standards, and about organic cotton production and certification between each segment. 
Table 3. T-tests of Factors between Each Consumer Segment ( $\mathrm{N}=332)$.

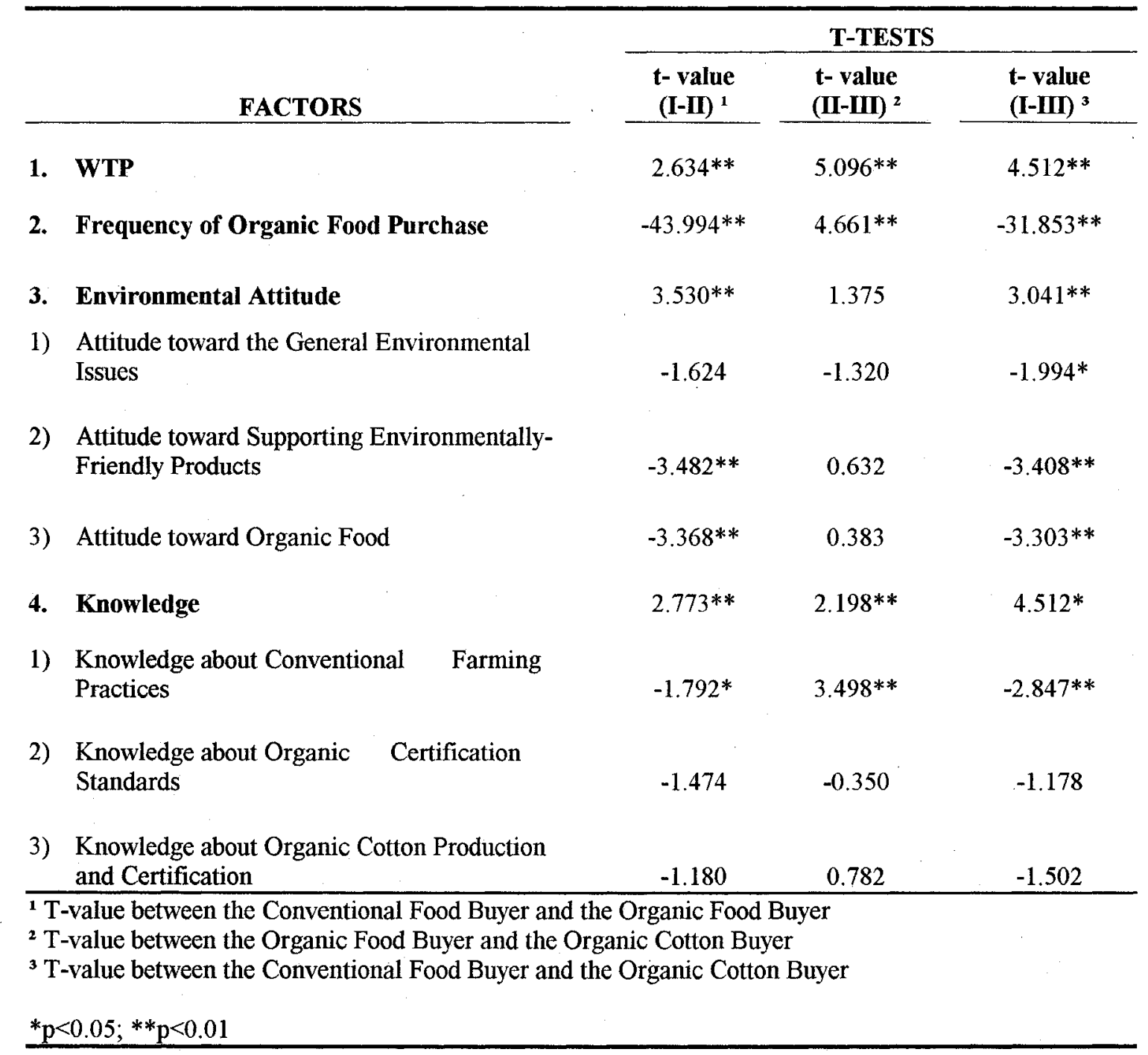

Motivations for Buying Organic Cotton Clothing. Respondents were asked to provide their motivations and perceived barriers when buying organic cotton clothing in the Behavior section of the study survey. According to the survey responses, respondents in all three groups ranked organic cotton's superior environmental benefits and lowpesticide residue (or health benefits) as organic cotton clothing's major advantage or added value. Respondents in the Organic Cotton Buyer and Organic Food Buyer groups 
were also more concerned about organic cotton farming's safer working conditions than those in the Conventional Food Buyer. In addition, almost $20 \%$ of conventional food buyers considered affordable product price as an important motivations for purchasing organic cotton products, compared to less than 5\% in Organic Food Buyer and Organic Cotton Buyer group (Figure 3).

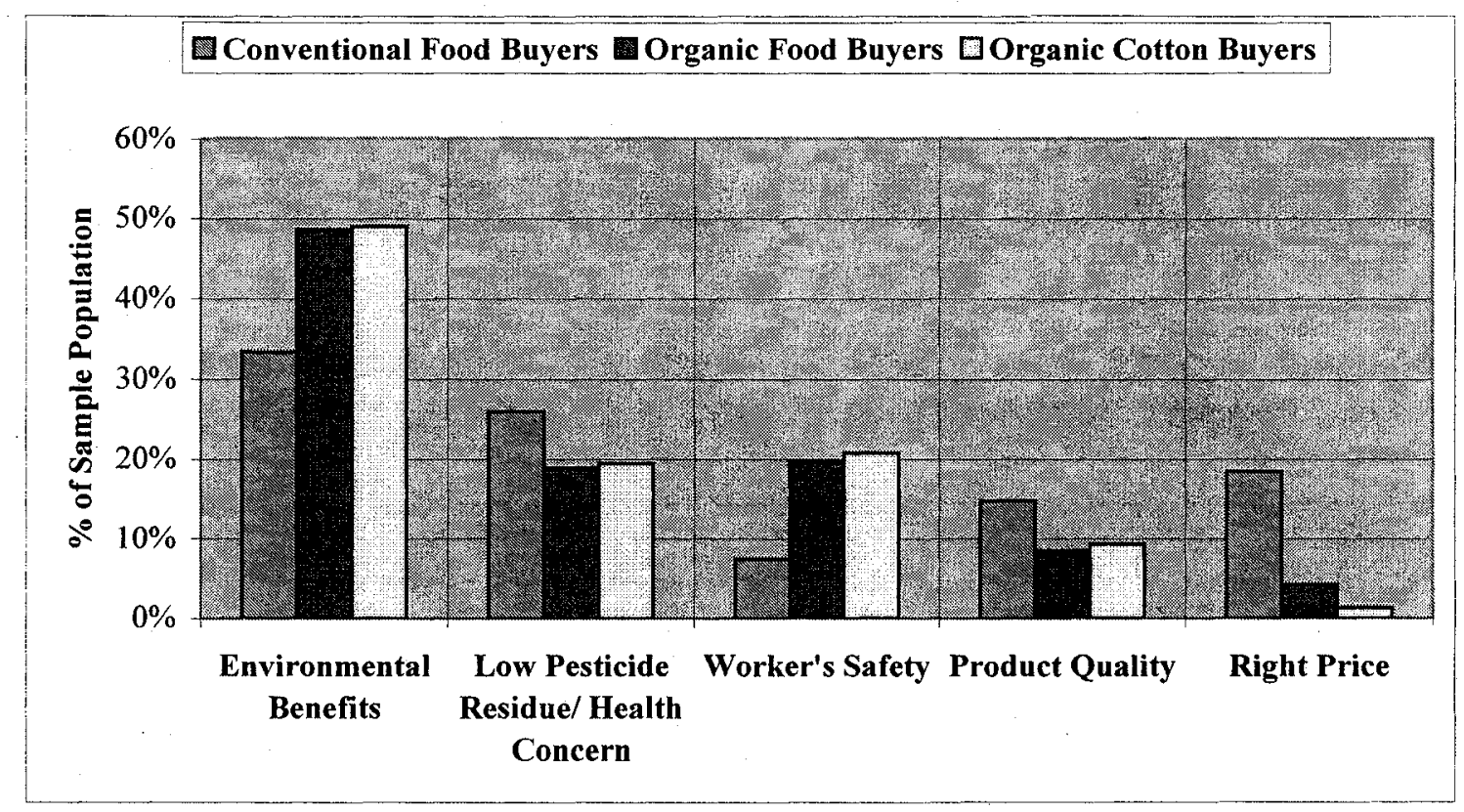

Figure 3. Consumer Motivations for Purchasing Organic Cotton Clothing.

Perceived Barriers. Figure 4 illustrates the major obstacles respondents had experienced when making purchase decisions on organic cotton clothing, and four major barriers were identified: high product price, poor product variety, lack of product information, and lack of distribution points. First, respondents across all three consumer segments described organic cotton's premium price as the major barrier. Both 
conventional food buyers and organic food buyers considered lacking information about organic cotton as the major reason for not buying organic cotton clothing, while organic food buyers and organic cotton buyers identified poor product variety and lack of distribution points as their top barrier. In addition, $20 \%$ of conventional food buyers also perceived organic cotton clothing as lack of obvious direct health benefits to them, compared to less than $5 \%$ of organic food buyers and organic cotton buyers.

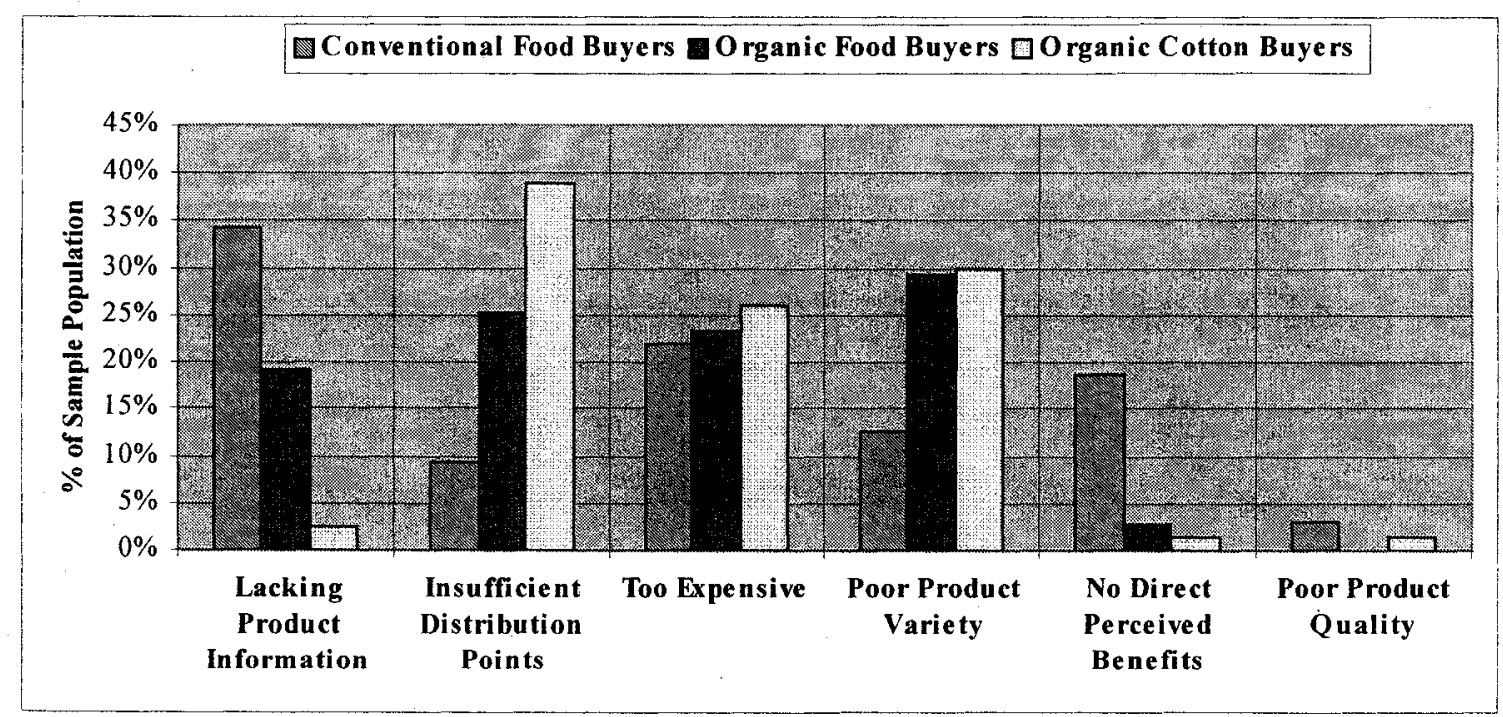

Figure 4. Perceived Barriers Influencing Consumers' Purchasing Decisions on Organic Cotton Clothing.

\section{Behavioral Analysis of Organic Food Purchasing}

Internal Factors Affecting Organic Food Purchase. As much as $94 \%$ of the study sample claimed they had purchased organic food at least once in the past three months, while $37 \%$ stated they purchased organic food every time they shopped. Two-tailed multiple regression analysis was applied to study the statistical associations between the 
frequency of organic food purchases and respondents' socioeconomic background, knowledge, and environmental attitudes. Multiple regression analysis indicated that the frequency of organic food purchase was significantly associated with gender, age, ethnicity, knowledge about organic farming practices and environmental attitudes (Table 4). Regression coefficients concluded that consumers who purchased organic food more frequently tended to be female, younger, white, more knowledgeable about organic farming practices, and have stronger positive environmental attitudes.

In addition, because survey data were collected from 3 different study sites in San Francisco, I further examined whether data collected from each individual study site had any biased effects on the overall result. This "site effect" was tested by including the study sites (Safeway and Trader Joe's) as dummy variables, and its effect on the frequency of organic food purchase was listed in the Model 2 in Table 4. The results showed that the site effect had a significantly negative impact on the frequency of organic food purchase. However, the inclusion of site effect didn't alter the statistical relationships between frequency of organic food purchase and related independent variables. 
Table 4. Coefficients and Standard Errors of Regression of Frequency of Organic Food Purchase on Independent Variables $(\mathrm{N}=329)$.

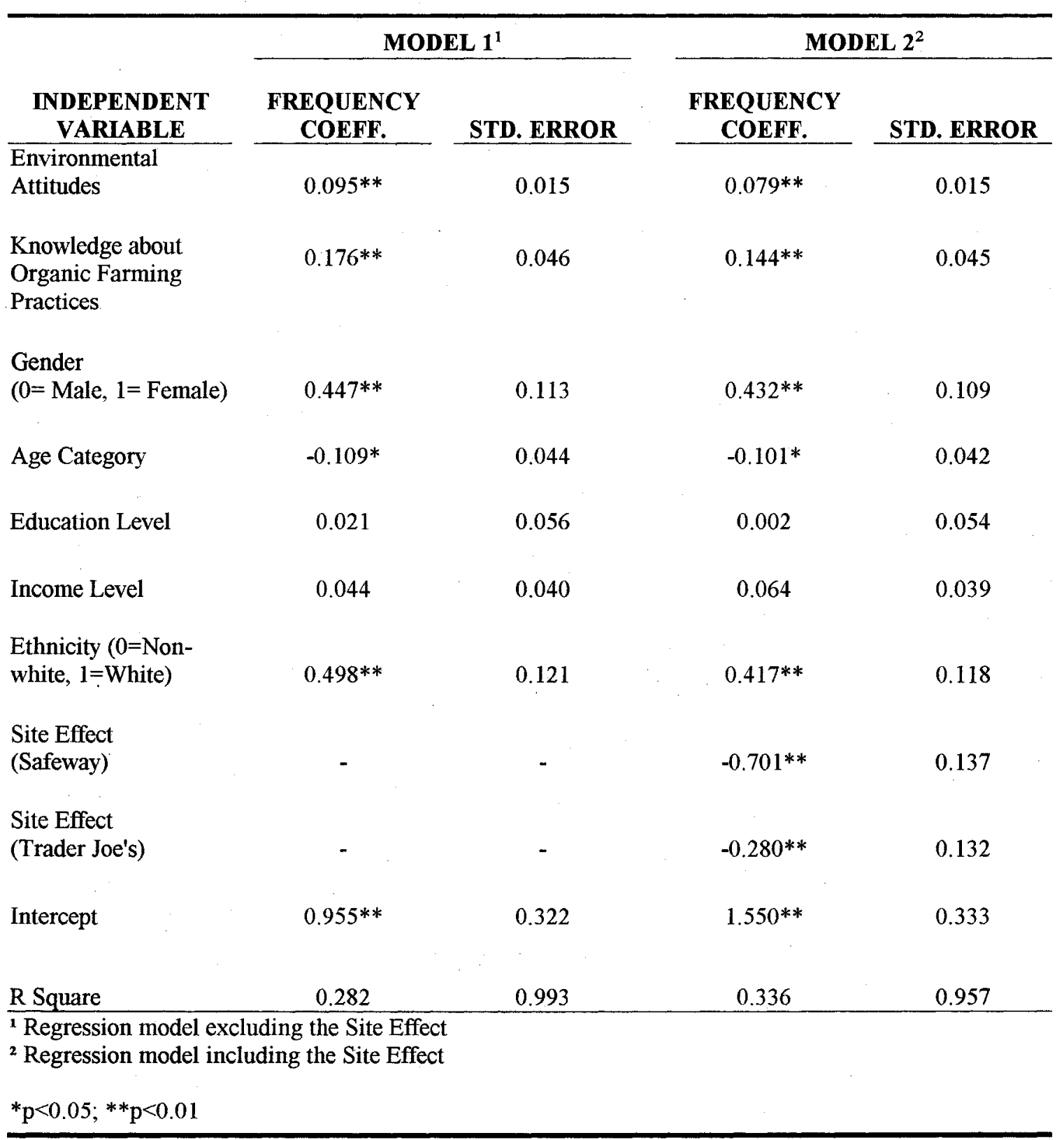


Behavioral Analysis of Organic Cotton Clothing Purchasing

Internal Factors Affecting WTP. Only $10 \%$ of the study sample stated they were not at all willing to pay more for an organic cotton t-shirt, while $30 \%$ stated they were extremely willing to do so. $52 \%$ of survey respondents were willing to pay a $50 \%$ price premium for an organic cotton t-shirt, while $25 \%$ was willing to pay at least $100 \%$ more over a conventional cotton t-shirt. Multiple regression analysis was applied to examine the associations between consumers' willingness to pay for an organic cotton t-shirt (WTP) and internal variables, including socioeconomic background, knowledge, environmental attitudes, and the frequency of organic food purchase. Statistical results from the three models 1 listed in Table 5 indicated that WTP was only correlated with environmental attitudes and the frequency of organic food purchase at $99 \%$ confidence level. Individuals with greater positive environmental attitudes, and higher frequency of organic food purchase were significantly more willing to pay a higher premium price for organic cotton clothing, while respondents' demographic background and knowledge had no effects on their WTP.

Model 2 in Table 5 also included the site effect on WTP. The results showed that the site effect had the similar negative impact on WTP as seen on the frequency of organic food purchase, but the site effect didn't alter the statistical relationship between WTP and independent variables.

In addition, Model 3 in Table 5 tested whether the frequency of organic food purchase overpowered the effects from other independent variables on WTP by excluding the frequency of organic food purchase from the multiple regression analysis. The results 
showed that the gender actually became a significant factor to consumer WTP when the effect from the frequency of organic food purchase was removed. This finding suggested that gender was an effective factor to WTP, but its effect was somehow suppressed by the effect from frequency of organic food purchase. 
Table 5. Coefficients and Standard Errors of Regression of Willingness to Pay (WTP) on Independent Variables $(\mathrm{N}=329)$.

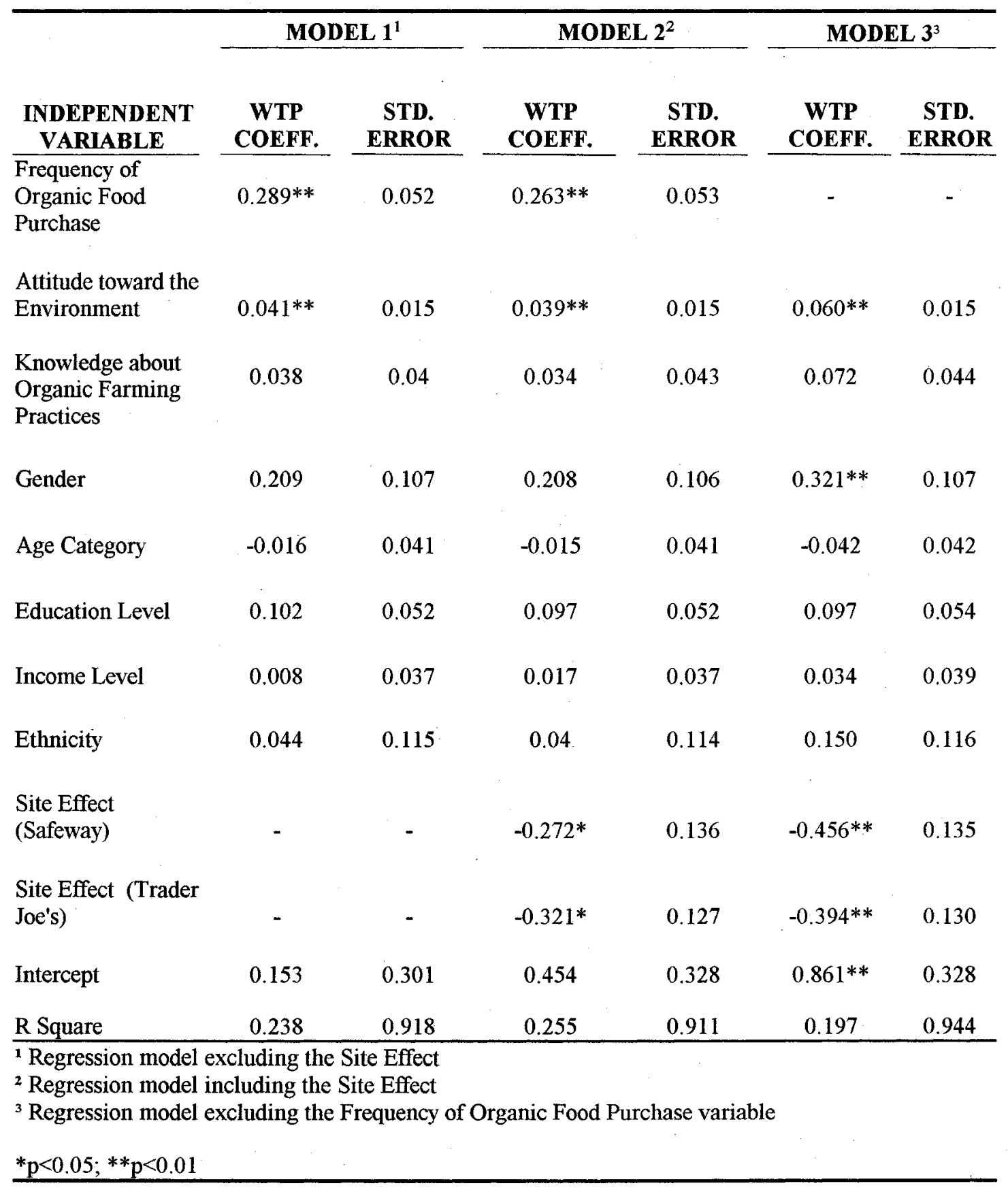


Internal Factors Affecting Organic Cotton Clothing Purchase Decision. Finally, the regression correlation analysis was applied to exam whether consumer stated WTP was a valid indicator of their actual purchase behavior through studying the associations between internal variables and survey participants' responses to the question of whether they have purchased organic cotton products in the past six months. Statistical analysis in Table 6 indicates that consumers who have purchased organic cotton products in the past six months tend to be female and tend to purchase organic food more frequently. In addition, the result also indicates a significant positive relationship between consumer decision on organic cotton clothing and their stated WTP; consumers who have purchased organic cotton clothing are willing to pay a higher price for organic cotton clothing than those who have never purchased it. The result suggests that consumer stated WTP is a statistically significant indicator of consumer actual purchase behavior. 
Table 6. Coefficients and Standard Errors of Regression of Purchase of Organic

Cotton Clothing on Independent Variables $(\mathrm{N}=329)$.

\begin{tabular}{|c|c|c|c|c|}
\hline \multirow[b]{2}{*}{$\begin{array}{c}\text { INDEPENDENT } \\
\text { VARIABLE }\end{array}$} & \multicolumn{2}{|c|}{ MODEL $1^{1}$} & \multicolumn{2}{|c|}{ MODEL $2^{2}$} \\
\hline & $\begin{array}{l}\text { REGRESSION } \\
\text { COEFF. }\end{array}$ & STD. ERROR & $\begin{array}{l}\text { REGRESSION } \\
\text { COEFF. }\end{array}$ & STD. ERROR \\
\hline WTP & $0.091^{* *}$ & 0.024 & $0.093 * *$ & 0.024 \\
\hline $\begin{array}{l}\text { Frequency of Organic } \\
\text { Food Purchase }\end{array}$ & $0.053 *$ & 0.023 & $0.049 *$ & 0.024 \\
\hline $\begin{array}{l}\text { Environmental } \\
\text { Attitudes }\end{array}$ & -0.006 & 0.007 & -0.007 & 0.007 \\
\hline $\begin{array}{l}\text { Knowledge about } \\
\text { Organic Farming } \\
\text { Practices }\end{array}$ & 0.023 & 0.019 & 0.022 & 0.019 \\
\hline $\begin{array}{l}\text { Gender } \\
(0=\text { Male, } 1=\text { Female })\end{array}$ & $0.112 *$ & 0.046 & $0.115^{*}$ & 0.046 \\
\hline Age Category & 0.008 & 0.017 & 0.008 & 0.017 \\
\hline Education Level & -0.023 & 0.022 & -0.024 & 0.022 \\
\hline Income Level & 0.011 & 0.016 & 0.012 & 0.016 \\
\hline $\begin{array}{l}\text { Ethnicity (0=Non- } \\
\text { white, } 1=\text { White })\end{array}$ & -0.011 & 0.049 & -0.016 & 0.049 \\
\hline $\begin{array}{l}\text { Site Effect } \\
\text { (Safeway) }\end{array}$ & - & - & -0.020 & 0.059 \\
\hline $\begin{array}{l}\text { Site Effect } \\
\text { (Trader Joe's) }\end{array}$ & - & - & 0.059 & 0.055 \\
\hline Intercept & -0.273 & 0.128 & -0.267 & 0.141 \\
\hline R Square & 0.137 & 0.390 & 0.143 & 0.390 \\
\hline $\begin{array}{l}{ }^{1} \text { Regression model ex } \\
{ }^{2} \text { Regression model in } \\
{ }^{*} \mathrm{p}<0.05 ;{ }^{*} \mathrm{p}<0.01\end{array}$ & $\begin{array}{l}\text { ding the Site Eff } \\
\text { ding the Site Eff }\end{array}$ & & & \\
\hline
\end{tabular}




\section{Discussion}

\section{Consumer Education}

Educating Consumers to Think Beyond Price Tags. The great success of organic food since the 1990s has indicated that a large number of today's consumers have learned to account for a product's direct and indirect costs and benefits when making purchasing decisions, and they therefore become willing to spend more to buy themselves safer food and support a cleaner environment. The same consumer education efforts must be incorporated into organic cotton marketing as well.

The huge subsidies ( $\$ 3.3$ billion in 2005 ) the conventional cotton industry has received every year have guaranteed the low production costs of conventional cotton. This has in turn enabled conventional cotton corporations to control the cotton price in the global market and leave hundreds of local cotton farmers in many developing countries unable to compete (Environmental Working Group, 2004; Ferrigno, 2005). U.S consumers must first be informed that the cheap cotton products they have been buying for decades are actually produced using their own tax contributions, so that the price tags of conventional cotton products do not truly reflect the actual costs to every American consumer - the loss of thousands of jobs in family farms and the deposition of one-third of a pound of chemical residue on every cotton t-shirt. Elzakker (1999) finds that if the environmental costs of cotton production, such as the costs to clean and prevent the pollution caused by pesticides, were incorporated into retail prices, a t-shirt made from conventional cotton actually costs $15 \%(\sim \$ 0.34)$ more than an organic one. Notice that this statistic has not yet included all of the indirect medical costs related to pesticide 
illnesses. Therefore, organic cotton marketers must first inform the consumers that the price tags of conventional cotton products do not nearly indicate their costs to the environment and society, and that the price premium of organic products should be considered cotton's "right" price.

Using Eco-labeling and Product Labels. An eco-label is the unique certification scheme that helps consumers to distinguish greener, more environmental-friendly products and services. Not only can an authentic and trustworthy eco-label can serve as an effective education and marketing tool by emphasizing the hidden values of certified products, it can also help green products to gradually push less environmentally-friendly products out of the market in the long-run (Grankvist, Gahlstrand, and Biel, 2004). In the United States, the implementation of USDA's organic seal has successfully increased consumer demands for organic food, and almost half of grocery shoppers claim they are aware of this label when shopping for organic food (Organic Trade Associate 2003). There is no doubt a well-designed eco-label will be an effective education tool in raising American consumers' awareness, and also develop their confidence in certified organic cotton products. However, unlike the USDA label for organic food, there is currently no government-authorized eco-label to certify finished organic cotton products. Such products sold in the United States can only be certified through international nongovernmental organizations, such as "SKAL" in the Netherlands, and the Soil Association in the United Kingdom, whose green seals carry very limited recognition in the United States. Nonetheless, the Organic Trade Association's (OTA) American 
the United States. Nonetheless, the Organic Trade Association's (OTA) American Organic Standards for Fiber Processing (currently under review and revision) is likely to become the first eco-label for organic cotton fabric in the United States in 2007.

Instead of applying eco-labels that are unfamiliar to most consumers on their products, I have found that most organic cotton suppliers in the U.S use their product labels as the main education tool for providing consumers with information about organic cotton. Most product labels across the various price ranges I have seen include the message that emphasizes organic cotton's environmental, social and health benefits. A product label collected from speesees, an organic cotton baby clothing company in San Francisco whose product prices range from $\$ 10$ to $\$ 40$ highlights the features and benefits of its organic cotton clothing- "use 100\% certified organic cotton, low-impact dyes... in sweatshop-free environments... creating a more sustainable future for the animal, plant and human." Similar information is also found on Wal-Mart's private organic cotton baby's clothing line "George," which targets the lower price range of the apparel market. George's product label emphasizes its organically-grown cotton as "extra soft," grown with "no pesticides, herbicides or synthetic fertilizers," which is "the way nature intended."

Education Taken Place in Retail Stores. Meyer (2001) finds that retail stores can also be an effective classroom for facilitating consumer education because most consumers unintentionally become aware of the existence of a new product when they shop, and they are more likely to read the product description if they find it interesting. Patagonia, one of pioneering apparel companies that switched to $100 \%$ organic cotton in 
these programs include the distribution of pamphlets and the displaying of banners which inform consumers of the benefits of organic cotton products (Chouinard and Brown, 1997). Other apparel specialty retailers such as Nike and Levi's, also gradually incorporate similar in-store education programs after launching their new organic cotton lines. Meanwhile, in addition to traditional "bricks-and-mortar" points of purchase, I have found most companies selling organic cotton products also provide detail information about organic farming practices and organic cotton on their websites.

In contrast, I have not found similar education programs installed in non-apparel retail stores. Wal-Mart, for example, has become the world's top organic cotton buyer since it launched its private organic baby clothing label "George" in 2005. Although Wal-Mart does provide information related to organic cotton production on George's product labels, neither its stores nor website provide any in-depth information about their organic cotton products. Organic cotton suppliers should encourage all retail stores carrying organic cotton products to conduct education programs inside the stores and on store websites.

Demarketing of Conventional Cotton Products. Browne and others (2000) believes that the most remarkable accomplishment of the organic movement is that consumers learn they have the power not only to send their messages to suppliers to show what they really want, but to boycott the products they disapprove of, a process called demarketing. The economic power of demarketing was specifically measured by the Cooperative Bank in the United Kingdom in 2005, in which researchers reported that $35 \%$ of British consumers felt guilty about unethical purchases, compared to only $17 \%$ in 
1999 , and it estimated that 296 million GBP $(\sim 580$ million USD) was spent by conscious consumers in boycotting apparel manufacturers that employ unethical practices such as abusing sweatshop labor or violating animal welfare (the Cooperative Bank, 2005). However, I have not found similar quantitative research focusing on conscious consumption in the United States. By demonstrating the collective economic power of conscious consumption, the conducting and release of such quantitative research is very likely to empower consumers and encourage them to purchase fewer conventional cotton products in any possible way.

Reducing Product Prices

High premium price has been identified by the survey respondents as the main barrier toward making organic products less appealing to a broader consumer base. However, simply reducing the sale price of organic cotton products by reducing its production costs could be problematic and unsustainable to the growth of organic cotton market.

As mentioned earlier, the annual sale of organic cotton products is expected to grow by $15.5 \%$ between 2004 and 2008 . Undoubtedly, a continuously increasing demand will both expand the current market and drop the production costs of organic cotton products in the long-run. In fact, consumers can already find a set of organic cotton baby clothing or an adult graphic $t$-shirt for as little as $\$ 8.00$ from Wal-Mart, that is almost the same price as the conventional cotton $t$-shirts sold in stores (Wal-Mart, 2006). However, Wal-Mart's "every-day-low-price" policy on organic products has provoked great concern from both organic farmers and advocates who believe overly 
reducing the price of organic products will actually diminish the fundamental value of organically grown products: supporting the health of people and the planet, and further reconnecting the bonds between food, people and the planet (Gogoi, 2006; Pollan, 2006). Latacz- Lohmann and Foster (1997) also points out that many consumers often treat price as the indicator of quality, so reducing the price premium of organic products might confuse those consumers who expect to pay more for products that are different from cheaper conventional ones. Besides, it is possible that many consumers will find a contradiction between the "brown" image of Wal-Mart, which has consistently been charged for its poor labor policies, and its new-found commitment to organic products. Thus, the bottom line of reducing the price premium of organic cotton products is that it will not work in isolation, and must be used with other marketing strategies (LataczLohmann and Foster, 1997). As a result, this section provides three possible solutions that will significantly reduce the costs of finished organic cotton products without jeopardizing farmers, retailers, or the core values of organic cotton.

Considering Using Other Sustainable Cotton. Because the primary objective of growing organic cotton is to eliminate the intensive use of synthetic chemicals that threaten the ecosystem, as well as farm workers and consumers, manufacturers could achieve this goal by using other sustainable fabrics. This could significantly reduce the production costs of sustainable textiles without trading off the environmental and social benefits gained with $100 \%$ organic cotton. For example, a fabric that contains at least $95 \%$ organic cotton can still be certified as "organic" according to Organic Exchange's OE 100 Standards. 
Another alternative that has been found successful in California is the use of cotton that is grown using integrated pest management (IPM) practices. Cotton farmers in California who participate in the Sustainable Cotton Project's BASIC program and apply IPM practices have significantly reduced their pesticide consumption by $70 \%$ over conventional cotton fields. Not only is BASIC's IPM cotton GMO-free, it costs almost $20 \%$ less than imported organic cotton, or $65 \%$ less than domestic organic cotton (Sustainable Cotton Project, 2005; L. Grose, personal communication, October 19, 2006). Products made using $95 \%$ organic blend as well as BASIC cotton provide manufacturers and consumers a middle ground between cheap but environmentally- unfriendly $100 \%$ conventional cotton, and expensive but environmentally- friendly $100 \%$ organic cotton.

Reducing Subsidies on Conventional Cotton Fields. Agricultural subsidies have been a complicated and controversial economic and political issue throughout their 70year history. It is difficult to predict all the possible outcomes of removing such huge subsidies on conventional cotton fields; however, the following cases will briefly reflect the effects that the removal of farm subsidies would have on organic cotton prices. Currently, the growing of organic cotton costs an average of $10 \%$ more than the growing of conventional cotton due to its labor-intensive practices. In India, one of the world's major organic cotton producers, conventional cotton farmers do not receive large subsidies on pesticides and other chemicals, and organic cotton actually costs $16 \%$ to $37 \%$ less to grow than conventional cotton because savings are made in buying fertilizers and pesticides (Elzakker, 1999). Similarly, in Egypt, another major organic cotton 
producer without large governmental subsidies, organic cotton production costs only $2 \%$ more than conventional cotton. On the other hand, regardless of the increasing demands for organically grown products, U.S organic farmers receive no government subsidies. Providing subsidies to organic farmers or reducing subsidies to conventional cotton farmers will not only reduce the costs of growing organic agricultural products, but it will also create incentives to increase domestic organic cotton supply and level the playing field between organic cotton and conventional cotton products in the long run.

Reducing Distribution Costs. Statistics show distribution costs tremendously raise the final prices of finished organic cotton products. An economic analysis on cotton production in Egypt highlights that, on average, a finished organic cotton t-shirt costs an extra $28 \%$ over a conventional cotton t-shirt ( $\$ 4.02$ vs. $\$ 3.24$ ) before it reaches distributors; however, after it is distributed to the retailers, the difference in retail prices could reach as high as $60 \%$ ( $\$ 23.51$ vs. $\$ 14.50$ ) (Elzakker, 1999). While it is difficult to ask retailers to reduce their mark-ups on organic cotton clothing, shortening the supply chain to reduce the number of 'middlemen' could be a realistic and practical pricing strategy. Obviously, the best solution to conserving the distribution costs is to "buy locally," which not only enables the suppliers to deal directly with local producers and reduce the distribution costs, but also guarantees the price premium local farmers receive and strengthens the domestic green economy. However, given the fact that domestic organic cotton often costs as much as three times more than imported organic cotton, most small and intermediate organic cotton suppliers have to choose to purchase from imported growers (L.Grose, personal communication, October 19, 2006). For suppliers 
who choose to purchase from foreign organic cotton producers, it has proven successful to adapt the integrated supply chain, in which buyers develop a direct contact and partnership with suppliers or farmers' unions to foster direct dialogue between buyers and local suppliers and growers, rather than going through multiple layers of middlemen (Ferrigno, 2005). Such practice is found successful in the Coop Switzerland, the second largest retailer in Switzerland. Coop Switzerland introduced its organic cotton line NATURALine in 1995, and during the initial launching of its new line, shortened the supply chain, excluded traders, and lowered other related transaction costs. Eventually, in this way, Coop Switzerland was able to sell NATURALine for almost the same price as conventional clothing (Meyers 2001). 


\section{Conclusion}

Internal Factors Affecting Consumer Purchase Behavior

Figure 5 illustrates the path analysis diagram of the causal relationships between internal factors that significantly affect consumer behavior in relation to the purchase of organic food and organic cotton clothing. Not only do consumers in the Organic Cotton Buyer group show a higher WTP than consumers in other groups, the regression analysis in Table 6 also suggests a positive correlation between WTP and consumers' actual buying behavior in the market place. Thus, the study first finds that consumers' stated WTP is an effective indicator of consumers' preference for organic cotton clothing over conventional cotton clothing.

In the study on specific consumer behavior, the path analysis indicates that consumer behavior of buying organic cotton is significantly associated with their behavior of buying organic food. First, consumer behavior of buying organic food is significantly associated with both consumers' demographic and psychographic background. In addition, both consumer behavior in buying organic food and organic cotton clothing follows the TRA model's assumption. The magnitude of attitude regression coefficients $(B=0.079$ and 0.060 respectively), however, indicates that the effect of environmental attitudes on environmentally-conscious behavior is statistically weaker than of other variables.

This study also finds that behavioral pattern, frequency of organic food purchase has the greatest effect on WTP $(B=0.263)$ among all internal variables and suggesting the consumers' behavioristic pattern seems to be the most effective approach segment in 
the target market of organic cotton products. This finding agrees with the study of Williams and Hammitt (2000), which finds that consumers who are more willing to support organic products tend to engage in health-promoting and environmentallyfriendly behavior, such as joining environmental organizations, recycling household trash, and buying environmentally-friendly detergents.

In addition to the behaviorisitc pattern, gender is the only demographic variable that has a significant impact on both consumers' behavior of buying organic food as well as of buying organic cotton. The magnitude of regression coefficients of gender $(B=0.432,0.208$ and 0.115$)$ suggest that gender plays a very effective determinant of consumer behavior among all internal variables, and female participants are more willing to engage in buying organic products than male. This finding agrees with the majority of previous studies because researchers believe women tend to be more concerned about the health of their children and other family members than men are (Gardyn, 2003; Hill and Lynchehaun, 2002; Laroche, Bergeron, and Barbaro-Forleo, 2001; Roberts, 1996; Tanner and Kast, 2003). 


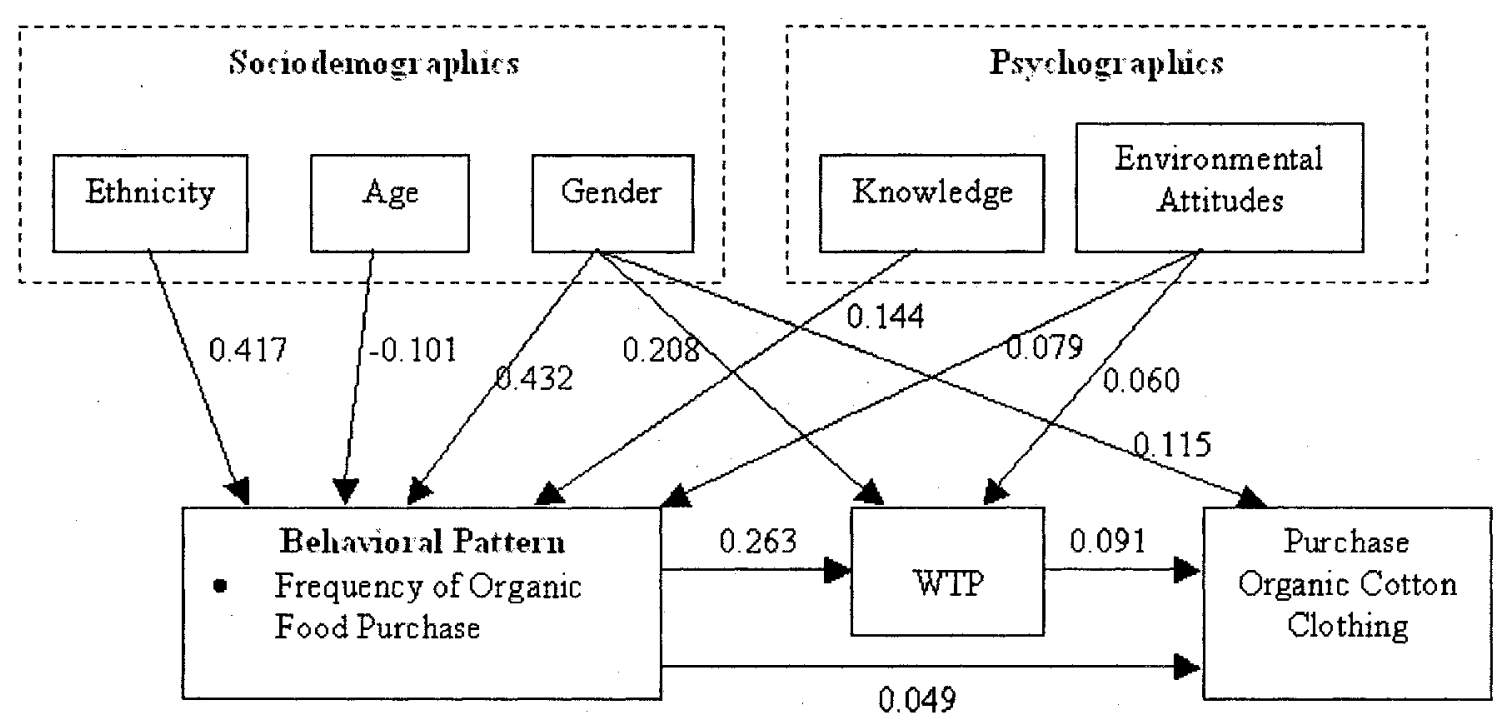

Figure 5. Path Analysis of Casual Relationships between Variables.

\section{Market Segmentation}

In this study, the study sample was grouped into three consumer segments based on their purchase behavior of organic food and organic cotton: the Conventional Food Buyer, the Organic Food Buyer, and the Organic Cotton Buyer. In their studies, Hartman (2004) and Lorek and Lucas (2003) cluster the potential market of sustainable fibers into three segments using a similar technique and set of criteria: the Dark Green "Core", the Light Green "Mid-level", and the Brown "Periphery." Correlating their findings with my study, in which consumers in the Organic Cotton Buyer group show superior knowledge and environmental attitudes, and greater willingness to buy organic cotton clothing, Organic Cotton Buyer would represent the Dark Green Core. Similarly, those in the Organic Food Buyer group, who show intermediate levels of knowledge, environmental attitudes, and buying preference for organic food, would represent the Light Green Midlevel. Researchers point out that although most green companies typically identify the 
Dark Green Core group as their major target customer group for its tendency to welcome new green products, the Light Green Mid-level actually plays the more critical role in triggering the take-off for the mass market of a new green product. Not only does the Light Green Mid-level often represent the majority of the consumer population, consumers in this segment are also more likely to become the opinion leaders and create the word-of-mouth promotion for new products. In addition, consumers in Light Green Mid-level are very likely to move into the Dark Green Core segment in the near future once they become familiar with new products and their features (Hartman, 2004; Lorek and Lucas, 2003; Rogers, 2003). Results from my survey study provide good news to organic cotton suppliers targeting the San Francisco Bay Area: not only does the San Francisco market include more "Deep Green Core" consumers than the Hartman Group's national average ( $22 \%$ vs. $13 \%$ ), but it also consists of a greater proportion of the "Light Green Mid-level" consumers ( $74 \%$ vs. $61 \%)$.

The Path from Brown to Light Green

The t-tests from Table 3 suggest that organic food buyers demonstrate stronger positive environmental attitudes and better understanding of the impacts of conventional farming than do conventional food buyers. It seems consumers' environmental attitudes and their knowledge both play an important determinant in the Brown to Light Green process (Figure 6). First, conventional food buyers will not be ready to switch to organic food and account for their higher monetary costs until they have better developed their environmental attitudes. Researchers believe an individual's attitude toward supporting environmentally-friendly products, also called green consumerism, is an important 
indicator of how confident an individual feels about their power to improve the world through their consumption behavior, and this attitude will determine people's willingness to adjust their current lifestyle and behavior in accordance with their beliefs and values (Brown and Walhers, 1998; and Roberts, 1996). Hence, once conventional food buyers' attitudes toward supporting organic products and participating in green consumption become more advanced, they become more willing to shift their lifestyle to engage in environmentally-conscious behavior, including purchasing organic products on a regular basis. Moreover, survey questions adapted from the New Environmental Paradigm aimed to measure consumers' attitude toward general environmental issues found no association between these attitudes and consumers' behavior in buying organic food. It suggests that respondents' environmental attitudes are selective and subject-related, and individuals' general environmental attitudes cannot be the common reference for all of their environmentally-conscious behavior.

On the other hand, consumers' environmental knowledge also plays an important role in transforming conventional food buyers into organic food buyers. Obviously, consumers will not choose to buy a new product until they have a greater understanding of the issues related relating to the product. Researchers also claim that advanced product knowledge not only correlates with higher probabilities for participating in the market, but it also plays an important key factor in overcoming some of the main obstacles a new product may encounter (Coyle, 2005; Soler and Gil, 2004; Young and others, 2006).

Descriptive statistics of survey respondents suggest that the majority of the study sample is only familiar with the negative impact of conventional farming (Mean=1.341), 
and has very limited knowledge about organic certification standards (Mean $=0.400$ ), and organic cotton (Mean= 0.475 ). It is possible that the questions in these two knowledge categories require consumers to have advanced training or specific knowledge, and thus were unable to test their influences on consumers' behavior of buying organic cotton clothing. As a result, respondents across different segments only show significant differences in their knowledge about conventional farming, and no difference in their knowledge about organic certification standards and organic cotton production and certification.

In addition, throughout this brown to green process, conventional food buyers continuously encounter external barriers that affect their willingness to buy organic food, such as organic food's premium prices, inconvenient store locations, and poor product appearance (Gil, Gracia, and Sanchez, 2000; Krystallis and Chryssohoidis, 2005; Zotos, Ziamou and Tsakiridou, 1999). 


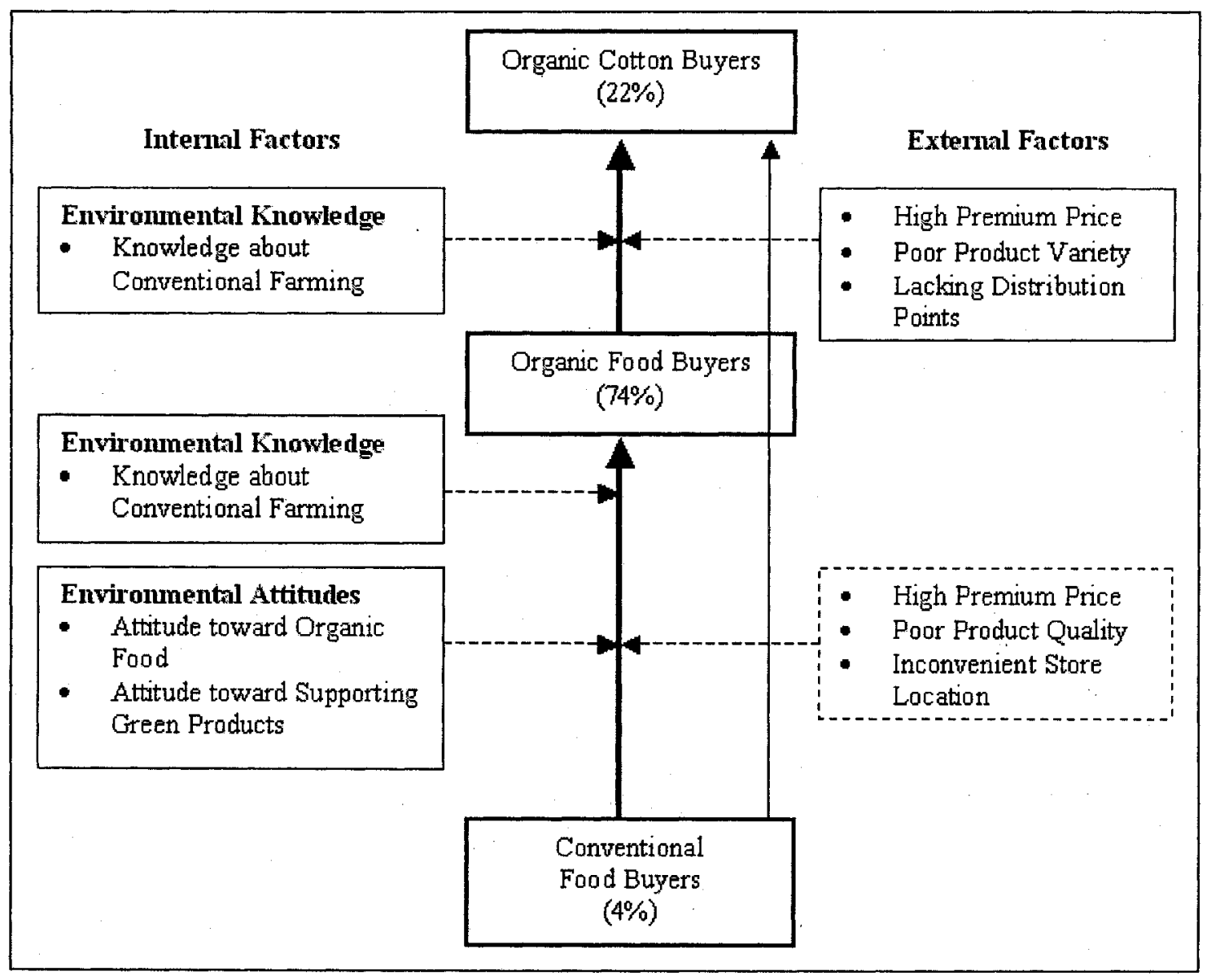

Figure 6. Factors Influencing Consumer Purchase Behavior on Organic Food and Organic Cotton Clothing.

\section{The Path from Light Green to Dark Green}

Consumers who decide to buy organic food are likely to go through a similar decision-making process regarding the purchase of organic cotton clothing.

Nevertheless, knowledge is the only determinant in this Light Green to Dark Green transition. Survey results report that $35 \%$ of conventional food buyers and $20 \%$ of organic food buyers consider the absence of product information to be the main reason for not buying organic cotton clothing, compared to only $3 \%$ in organic cotton buyers. 
Those who are less familiar with the issues related to organic cotton might consider organic cotton lacking significant and direct benefits to them. Education that specifically informs consumers about the environmental and social benefits of organic cotton products will help Light Green organic food buyers better understand the values of organic cotton products, and eventually overcome the external factors identified in the study survey, which include poor product variety (identified as the top obstacle by organic food buyers), lacking distribution channels, and high prices (Figure 4). This understanding will prompt them to try organic cotton products and increase their willingness to pay for organic cotton clothing.

Finally, Figure 6 also demonstrates an alternative route, in that conventional food buyers can bypass becoming organic food buyers, and instead become organic cotton buyers. However, the survey shows that only three out of 89 organic cotton buyers state they never purchased organic food, while the rest of organic cotton buyers have purchased organic food on a regular basis. As a result, this study conclude that the majority of the consumers would go through this three-stage process prior to buying organic cotton clothing.

\section{Product Positioning}

Although the study survey indicates that organic cotton's superior environmental benefits remain the dominant attribute attracting consumers across all segments, Kevin Myette, the Research and Development Director of Recreational Equipment, Inc. (REI), believes organic cotton clothing's environmental benefits would become an important added-value to customers only if they provide similar performance, quality, and design as 
other clothing sold in the stores (K. Myette, personal communication, April 5, 2007).

Previous market research also confirms that a green product's environmentally or socially-friendly attributes can no longer be the only selling proposition attracting today's consumers, who will only choose to buy organic cotton clothing if they first receive the same quality of product attributes that they receive from the similar conventional alternatives (Hartman, 1999; Meyer, 2001; Rogers, 2003). Almost all organic cotton suppliers I have personally communicated with have provided the similar comments about the bottom line of positioning organic cotton clothing - the environmental benefit of organic cotton is just one of the many attributes mainstream consumers consider when making purchasing decisions. Consumers will not buy organic cotton clothing only because it is environmentally friendly. In other words, organic cotton's superior environmental and social benefits would only be an "emotionally feel better" added-value today's consumers (Meyer, 2001).

Shaw and Clarke (1999) suggest that consumers are more likely to buy a green product if it includes the added-values that closely relate to the issues with which they are already familiar. In addition to emphasizing organic cotton's environmental benefits, I find organic cotton suppliers have not yet placed enough emphasis on the potential health and social benefits of organic cotton clothing, such as its naturally hypoallergenic qualities and the implementation of fair labor practices. Furthermore, some organic cotton suppliers also believe that many consumers still consider organic cotton clothing to be "without fashion and color, and boring" (Lorek and Lucas, 2003). Organic suppliers should incorporate more designs, colors, and product variety into organic cotton clothing 
in order to eradicate this stereotypical image (Lorek and Lucas, 2003; K. Myette,

personal communication, April 5, 2007; R. Pearson, personal communication, April 26, 2007). 


\section{References}

Anderson, R.C., and Hansen, E.N. (2004). The impact of environmental certification on preferences for wood furniture: A conjoint analysis approach. Forest Products Journal, 54(3): 42-50.

Bang, H., Ellinger, A., Hadjimarcou, J., and Traichal P. (2000). Consumer concern, knowledge, belief, and attitude toward renewable energy: An application of the Reasoned Action Theory. Psychology and Marketing, 17(6): 449-468.

Bay Area Census (2005). U.S. Census: American Community Survey 2005 in Bay Area Census. Retrieved November 15, 2006, from http://census.abag.ca.gov/bayarea.htm

Bhatnagar, P. (2006, May 1). Wal-Mart's next conquest: Organic. CNN Money Online. Retrieved May 13, 2007 from http://money.cnn.com/2006/05/01/news/companies/walmart_organics/index.htm

Browne, A.W., Harris, P.J.C., Hofny-Collins, A.H., Pasieczink, N. and Wallace, R.R. (2000). Organic production and ethical trade: definition, practice and links. Food Policy, 25: 69-89.

Brown, J.D. and Wahlers, R. G. (1998, Spring). The environmentally concerned consumer: an exploratory study. Journal of Marketing, 6(2): 39-47.

Burden, G. (2004). Getting to 10\% by Building Markets, Supporting Innovation and Transparency. In Organic Exchange Fall 2004 Conference, Hong Kong. Retrieved November 15, 2006, from http://www.organicexchange.org/meetings/presents/china_marks.htm

California Department of Pesticide Regulation (2002). Summary of Pesticide Use Report Data 2002 Indexed by Commodity. Sacramento, CA: Office of Pesticide Regulation. Retrieved April 13, 2006, from http://www.cdpr.ca.gov/docs/pur/pur02rep/02com.htm

Chan, K. (1999). Market segmentation of green consumers in Hong Kong. Journal of International Consumer Marketing, 12(2): 7-24.

Chouinard, Y., and Brown, M.S. (1997). Going organic: converting Patagonia's cotton product line. Journal of Industrial Ecology, 1(1): 117-129. 
Coody, L.S., Riddle, J.A., and Rosen, E.B. (2003). The Organic Trade Association's American Organic Standards, Version 2. The Organic Trade Association.

Retreved April 13, 2006, from

http://www.ota.com/AmericanOrganicStandardsforFiber.html

The Cooperative Bank, U.K. (2005, November 27). Ethical Consumerism Report.

Retrieved December 20, 2006, from

http://www.cooperativebank.co.uk/images/pdf/coopEthicalConsumerismReport20 05.pdf

Coyle, D. (2005, September). Environmental Literacy in America: what ten years of NEETF/Roper research and related studies say about environmental literacy in the U.S. National Environmental Education and Training Foundation (NEETF). Retrieved March 25, 2006, from http://www.neefusa.org/pubs/ELR2005.pdf

Cranfield, J.A. and Magnusson, E. (2003). Canadian consumer's willingness to pay for pesticide free food products: A ordered probit analysis. International Food and Agribusiness Management Review, 6(4): 13-30.

Dimitri, C. and Greene, C. (2002, September). Recent growth patterns in the U.S. organic foods market. Economic Research Service/ USDA. AIB777. Retrieved Jan 10, 2007, from http://www.ers.usda.gov/publications/aib777

Dunlap, R.E. and Van Liere, K.D. (1978). The New Environmental Paradigm: A proposed measuring instrument and preliminary results. Journal of Environmental Education, 9(4): 10-19.

Economic Research Service/ USDA. (1996, July). Summary of report. Cotton acreage gains of past decade reverse 60-year decline. AER-739. Retrieved January 10, 2007, from http://www.ers.usda.gov/Publications/Summaries/cotton.htm

Economic Research Service/ USDA. (2007, July 5). Adoption of genetically engineered crops in the U.S.: cotton varieties. Retrieved July 8, 2007, from http://www ers.usda.gov/data/BiotechCrops/

Elzakker, B.V. (1999, March). Comparing the costs of organic and conventional cotton. In Myers, D. and Stolton, S. (Eds.), Organic cotton: from field to final products. Intermediate Technology Development Group Publishing, United Kingdom.

Environmental Working Group. (2004). EWG Farm Subsidy Database 1995-2005.

Retrieved January 10, 2007, from

http://farm. ewg.org/farm/region.php?fips $=00000$ 
Ferrigno, S. (2005, August). Moral fibre: A beginner's guide to the UK market. Pesticide Action Network, UK.

Fishbein, M., and Ajzen, I. (1975). Belief, attitude, intention, and behavior: An introduction to theory and research. MA: Addison- Wesley. Retrieved October 6, 2005, from http://www.people.umass.edu/aizen/f\&a1975.html

The Fabric of Their Lies: Cotton's Devastating Legacy. (2002, September 30). Food and Water Journal. Montpellier.

Gardyn, R. (2003, October). Eco-friend or foe? American Demographics, 25(8): 12

Gil, J.M. Gracia, A., and Sanchez, M. (2000). Market segmentation and willingness to pay for organic products in Spain. International Food and Agribusiness Management Review, 3: 207-226.

Gogoi, P. (2006, March 29). Wal-Mart's Organic Offensive. Business Weekly. Retrieved March 23, 2007, from http://www.businessweek.com/bwdaily/dnflash/mar2006/nf20060329_6971.htm

Golding, K. and Peattie, K. (2005). In search of a golden blend: perspectives on the marketing of fair trade coffee. Sustainable Development, 13: 154-165.

Grankvist, G., Dahlstrand, U., and Biel, A. (2004). The impact of environmental labeling on consumer preference: negative vs. positive. Journal of Consumer Policy, 27(2): 213-230.

Greene, C.R. (2003, April 1). U.S. organic farming emerges in the 1990s: A adoption of certified systems. USDA- ERS, Agriculture Information Bulletin No. 770. Retrieved January 10, 2007, from http://www.ers.usda.gov/Publications/AIB770

Grose, L. (2006, October 19). Sustainable Cotton Project. Personal communication.

Grunert, S.C. and Juhl, H.J. (1995). Values, environmental attitudes, and buying of organic foods. Journal of Economic Psychology, 16: 39-62.

Guagnano, G.A. (2001). Altruism and market-like behavior: An analysis of willingness to pay for recycled paper products. Population and Environment, 22(4): 425-438.

Hamm, U. (1995). Gemeinsam neue Wege in der Vermarktung beschreiten, in LataczLohmann and Foster 1997. 
Hartman, H. (1999). Marketing to the new natural consumer: Consumer trends forming the wellness category. The Hartman Group, Washington.

Hartman, H. (2004). Consumer perspectives on organic fiber and sustainability. Presented to the Organic Exchange. Retrieved January 15, 2007, from http://www.organicexchange.org/meetings/presents/BHHPOR6.pdf

Hines, J.M., Hungerford, H.R., and Tomera, A.N. (1987). Analysis and synthesis of research on responsible environmental behavior: A meta- analysis. Journal of Environmental Education, 18: 1-8.

Hill, H., and Lynchehaun, F. (2002). Case study. Organic milk: attitudes and consumption pattern. British Food Journal, 104(7): 526-542.

Hunter, L.M., and Rinner, L. (2004). The association between environmental perspective and knowledge and concern with species diversity. Society and Natural Resources, 17: 517-532.

Ingram, M. (2002). Producing the natural fiber naturally: Technological change and the US organic cotton industry. Agriculture and Human Values, 19: 325-336

Jan, M., Fu, T., and Huang, C. (2004). Willingness to pay for low-lung-cancer-risk cigarettes in Taiwan. Health Economics, 14: 55-67.

Jensen, A., Mazhitova, Z., and Zetterstrom, R. (1997). Environmental pollution and child health in the Aral Sea region in Kazakhstan. The Science of the Total Environment, 206: 187-193.

Kassarjian, H.H. (1971, July). Incorporating ecology into marketing strategy: the case of air pollution. Journal of Marketing, 35: 61-65.

Kinnear, T.C., and Taylor, J.R. (1973, May). The effect of ecological concern on brand perceptions, Journal of Marketing Research, 10: 191-197.

Kerin, R.A., Hartley, S.W., and Rudelius, W. (2004). Marketing: the core. McGrawHill/ Irwin Company, Inc., New York.

Krystallis, A., and Chryssohoidis, G. (2005). Consumers' willingness to pay for organic food: Factors that affect it and variation per organic product type. British Food Journal, 107(5): 320-343.

Lackman, M. and Lackman, S. (2006, October to December). Certified Organic Fiber and Clothing:Fashioning Best-Practice Global Standards. Organic Processing Magazine. 
Laroche, M., Bergeron, J., and Barbaro-Forleo, G. (2001). Targeting consumers who are willing to pay more for environmentally friendly products. Journal of Consumer Marketing, 18(6): 503-520.

Latacz-Lohmann, U. and Foster, C. (1997). From niche to mainstream- strategies for marketing organic food in Germany and the UK. British Food Journal, 99 (8) 275-282.

Lea, S. and Webley, P. (1997, February 21). Topic 3: Path Analysis. University of Exeter, Department of Psychology, Washington Singer Laboratories. Retrieved November 23,2006, from http://www.people.ex.ac.uk/SEGLea/multvar2/pathanal.html

Liu, J., Hammitt, J.K., Wang, J. and Tsou, M. (2005). Valuation of the risk of SARS in Taiwan. Health Economics, 14(1), p83-91.

Lohr, L. (2001). Factors affecting international demand and trade in organic food products. Changing structure of global food consumption and trade/ WRS-01-1. Economic Research Service/USDA. Retrieved June 6, 2006, from http://www.ers.usda.gov/publications/wrs011/wrs011j.pdf

Lohr, L. and Semali, A. (2000). Retailer decision making in organic produce marketing, in Lohr, 2001

Lorek, S. and Lucas, R. (2003, June). Toward sustainable market strategies: A case study on eco-textiles and green power. Wuppertal Institute for Climate, Environment and Energy. Wuppertal paper No.130.

Lotus Organics (2004). Retrieved July 1, 2007, from www.lotusorganics.com

Louviere, J. 1996. Relating stated preference measures and models to choices in real markets: calibration of CV responses. In Bjornstad, D.J. and Kahn, R.J. (eds.). The Contingent Valuation of Environmental Resources. Cheltenham: UK.

Meyer, A. (2001, September/ October). What's in it for the customers? Successfully marketing green clothing. Business Strategy and the Environment, 10(5).

McCarthy, J.A., and Shrum, L.J. (1994). The recycling of solid wastes: personal value orientations, and attitudes about recycling as antecedents of recycling behavior. Journal of Business Research, 30: 53-62.

Myers, S. and Stolton, S. (1999). Organic Cotton: From Field to Final Product. Intermediate Technology Development Group Publishing, United Kingdom.

Myette, K. (2007, April 5). Personal Communications. 
Organic Exchange. (2006, Spring). Organic Cotton Market Report, Executive Summary. An in-depth look at a growing global market. Retrieved January 10, 2007, from http://www.organicexchange.org/Documents/marketreport_2006.pdf

Organic Trade Associate. (2003, April 23). New poll shows women aware of "USDA Organic" seal. Retrieved April 15, 2006, from http://www.ota.com/news/press/108.html

Organic Trade Associate. (2006). Organic cotton facts. Retrieved November 28, 2005, from http://www.ota.com/organic/mt/organic_cotton.html

Ottman, J. (1994). Green Marketing (2 ${ }^{\text {nd }}$ Ed.). NTC Business Books, Chicago.

Pearson, R. (2007, April 26). Personal Communications.

Philip, L.J. and MacMillan, D.C. (2005). Exploring values, context and perception in contingent valuation studies: The CV market stall technique and willingness to pay for wildlife conservation. Journal of Environmental Planning and Management, 48(2): 257-274.

Pesticide Action Network North America (PANNA). (1998). Problems with conventional cotton production, excerpted from in Organic Cotton Briefing Kit. Retrieved January 22, 2007, from http://www.panna.org/resources/documents/conventionalCotton.dv.html

Pollan, M. (2006). The omnivore's dilemma, a natural history of four meals. The Penguin Press, New York.

Raab, C. and Grobe, D. (2005, August). Consumer knowledge and perception about organic food. Journal of Extension, 43(4). 4RIB3. Retrieved October 5, 2005, from http://www.joe. org/joe/2005august/rb3.shtml

Rogers, E.M. (2003). Diffusion of Innovation (5th Ed.). Free Press, New York.

Roberts, J.A. (1996). Green consumers in the 1990s: profile and implications for advertising. Journal of Business Research, 36: 217-231.

Roberto, K. (1989). Social Marketing, strategies for changing public behavior. The Free Press, New York.

Roe, B., Teisl, M.F., Levy, A., and Russell, M. (2001). US consumers' willingness to pay for green electricity. Energy Policy, 29: 917-925.

Scott, M. (1997, June). Organic dairy a cash cow. Natural Foods Merchandiser. 
Shaw, D. and Clarke, I. (1999). Belief formation in ethical consumer groups: an exploratory study. Marketing Intelligence and Planning, 17 (2): 109-120

Stern, P.C. (1999). Information, Incentives, and Proenviornmental Consumer Behavior. Journal of Consumer Policy, 22: 461-478.

Soler, F. and Gil, J.M. (2004, November). Relationship between knowledge and willingness to pay for organic food in Spain: Evidence from experimental auction. Selected paper prepared for presentation at the NJF. Seminar 366: "Food consumption behavior." Copenhagen, Demark, 16-17.

Sustainable Business.com. (2006, March 29). Safeway: organic food contender? Retrieved January 23, 2007, from http://www. sustainablebusiness.com/features/feature_template.cfm? ID=1321

Sustainable Cotton Project. Retrieved June 20, 2005, from http://www.sustainablecotton.org/

Tanner, C., and Kast S.W. (2003). Promoting sustainable consumption: determinants of green purchases by Swiss consumers. Psychology and Marketing, 20(10): 883902.

The U.S. Centers for Disease Control and Prevention. (2003, October). Second National Report on Human Exposure to Environmental Chemicals. Retrieved June 15, 2005 , from http://www.cdc.gov/exposurereport/

Tracy, A.P., and Oskamp, S. (1983). Relationship among ecologically responsible behaviors. Journal of Environmental System, 13(2): 115-126.

U.S. Census. (2000). U.S. Census Bureau. Retrieved October 15, 2006, from http://www.census.gov/main/www/cen2000.html

Wal-Mart. (2006). Retrieved May 2, 2007, from http://www.walmart.com

Williams, P.R.D. and Hammitt, J.K. (2000). A comparison of organic and conventional fresh produce buyers in the Boston area. Risk Analysis, 20(5): 735-745.

Zotos, Y., Ziamou, P., and Tsakiridou, E. (1999, Spring). Marketing organically produced food products in Greece: challenge and opportunities. Greener Management International, 25: 91-104. 
Appendices

Appendix A. Shopping Survey

\section{San Jose State University Graduate Study Survey}

Thank you for participating in my graduate research survey. The questionnaire that you are filling out asks you questions about your attitudes, knowledge, behaviors, and demographic characteristics. We are gathering this information so that we can better understand how the general public feels about certain issues and products. Your participation in my study is completely voluntary, and you have the right not to answer any or all of the questions. All of your responses will be kept confidential, and your name will not be associated with any information you provide.

Again, many thanks for helping me out with my graduate research project. If you have any additional questions about the survey, please address to me, Pete Wang. You can reach me at 415-200-9874 or email me at chunpei2001@yahoo.com 


\title{
SJSU Graduate Study Environmental Attitude and Knowledge Survey
}

\author{
This section of the survey asks for your opinions on a \\ variety of issues. Your honest answers will help us better \\ understand how consumers feel about certain practices and \\ products.
}

\section{Knowledge}

Please answer the following questions regarding organic products:

1. How would you rate your level of knowledge about organic farming practices?

$\begin{array}{llll}\square \text { Not at all } & \square \text { Somewhat } & \text { Extremely } & \square \text { No Opinion } \\ \text { Knowledgeable } & \text { Knowledgeable } & \text { Knowledgeable } & \end{array}$

2. The acronym NOP stand for Natural Order of the Plant.

口Yes $\square$ No aDon't Know

3. "Conventional agriculture" (large scale, monoculture farming practices) often severely pollutes the environment.

口Yes प्ano aDon’t Know

4. According to the standards from the United States Department of Agriculture (USDA), farmers are not allowed to use synthetic or nonsynthetic pesticides and fertilizers on organic fruits and vegetables during the production.

$\square$ Yes $\square$ No

DDon't Know

5. In general, making one cotton t-shirt requires a small amount of pesticide that cannot be detected by scientific instruments.
पYes $\square$ No
aDon't Know

6. In general, synthetic pesticides are more toxic to humans than nonsynthetic pesticides.

पYYes ano aDon't Know

7. Currently, a finished garment made with organic cotton can be certified as organic by the USDA. 
Behaviors

1. Suppose you are about to purchase a cotton t-shirt at one of your favorite retail clothing stores. All things being equal, how willing would you be to pay more for the same t-shirt if is made with organic cotton?
$\square$ Not at all willing
$\square$ Somewhat
DExtremely
(Skip to 3.)
Willing
Willing
DDon't Know/ No
Opinion

2. Continuing on the previous question, suppose the cotton t-shirt you are about to purchase at your favorite store costs $\$ 10$. All things being equal, what is the maximum price premium you will be willing to pay for the same t-shirt made with organic cotton? (Check ONE of the following)

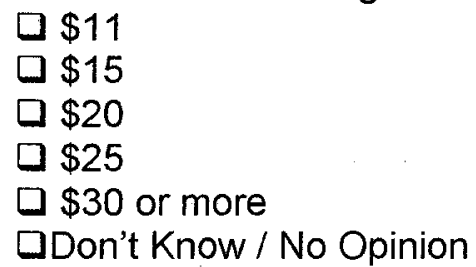

3. In the past 3 months, approximately how often have you purchased organic food or/ and vegetables?

$\square$ Never

$\square$ Less than once per month

$\square$ Between once to 3 times per month

$\square 4$ or more times per month

aEvery time I shop, I buy organic

4. Over the past 6 months, have you purchased clothing made with organic cotton as a gift or for yourself?

$\square$ YES

$\square$ NO

Don't Know / No Opinion

4 (a). In your opinion, what are the 2 MOST IMPORTANT reasons for you to purchase organic cotton clothing?

I Environmental benefits

$\square$ Lower pesticide residue (product safety)

$\checkmark$ Safer working conditions

$\square$ Good product quality

$\square$ Right price 
4 (b). Based on your experience and understanding, what reasons explain why you do not buy organic cotton clothing? (Check all that apply)

- Do not know or ever hear anything about organic cotton

$\square$ Cannot find stores selling organic cotton products

$\checkmark$ It is usually too expensive

$\checkmark$ Clothing made with organic cotton does not come in enough styles or types of products

$\square$ Do not see any direct benefits of buying it

$\square$ It has bad product quality

\section{Attitudes}

Which of the following responses best describes your attitudes about the following statements:

1. If things continue on their present course, we will soon experience a major ecological disaster.

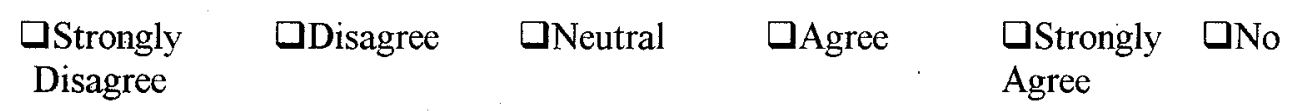

Opinion

2. I am willing to cut my current living standard to protect the environment.

口Strongly

口Disagree $\square$ Neutral $\square$ Agree

uStrongly $\square$ No

Disagree

Agree

Opinion

3. Current claims that environmental problems are changing the earth's climate are exaggerated.

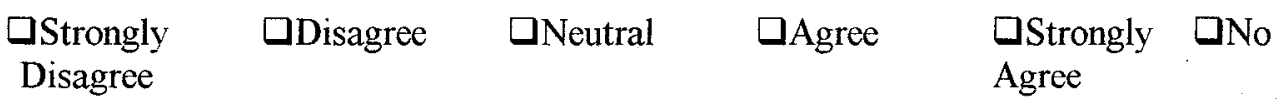

Opinion

4. The consumer has the power to force products that pollute the environment off the market.

口Strongly

aDisagree $\square$ Neutral $\square$ Agree

$\square$ Strongly $\square$ No

Disagree

Agree

Opinion 
5. All things considered, organic foods are no different than conventional

$\begin{array}{lllll}\text { DStrongly } & \square \text { Disagree } \\ \text { Disagree } & \square \text { Neutral } & \square \text { Agree } & \begin{array}{l}\text { QStrongly } \\ \text { Agree }\end{array} & \\ & & & & \text { Opinion }\end{array}$

foods.

6. People should buy environmentally-friendly products, even though they are sometimes more expensive.

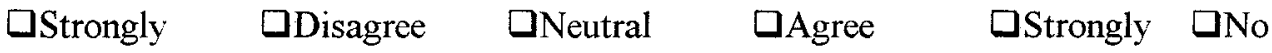

Disagree Agree

Opinion

Demographics

1. Your Gender

aMale DFemale

2. Your Age

3. Highest Education Level Completed

aLess than high school DHigh school aAssociate/ Junior College

$\square$ Bachelor $\square$ Graduate and above

4. Your MONTHLY Personal Income

$\square \$ 0-2000 \square \$ 2,001-3,000 \quad \square \$ 3,001-4,000 \quad \square \$ 4,001-5,000$

$\square \$ 5,000$ and above

5. What is your ethnicity? (Check all that apply)

White

B Black or African American

a Spanish/Hispanic/Latino

a Asian or Pacific Islander

- American Indian or Alaskan Native

a Other 
Appendix B. Survey Coding

Knowledge

1. How would you rate your level of knowledge about organic farming practices?

पNot at all QSomewhat QExtremely

Knowledgeable Knowledgeable Knowledgeable
(0)
(1)
(2)

2. The acronym NOP stand for Natural Order of the Plant.

口Yes (0) प्रo (1)

3. "Conventional agriculture" (large scale, monoculture farming practices) often severely pollutes the environment.

aYes (1) प $\quad$ No (0)

4. According to the standards from the United States Department of Agriculture (USDA), farmers are not allowed to use synthetic or nonsynthetic pesticides and fertilizers on organic fruits and vegetables during the production.

पYes (0) प्रNo(1)

5. In general, making one cotton t-shirt requires a small amount of pesticide that cannot be detected by scientific instruments.

प्Yes $(0)$

ano

6. In general, synthetic pesticides are more toxic to humans than nonsynthetic pesticides.

पYYes (1) $\quad \square$ No (0)

7. Currently, a finished garment made with organic cotton can be certified as organic by the USDA.

$$
\text { بYes (0) } \quad \text { No (1) }
$$

\section{Behaviors}

1. Suppose you are about to purchase a cotton t-shirt at one of your favorite retail clothing stores. All things being equal, how willing would you be to pay more for the same t-shirt if is made with organic cotton?
$\square$ Not at all willing
$\square$ Somewhat
Willing
DExtremely
(Skip to 3.)
Willing

(1)

(2) 
2. Continuing on the previous question, suppose the cotton t-shirt you are about to purchase at your favorite store costs $\$ 10$. All things being equal, what is the maximum price premium you will be willing to pay for the same t-shirt made with organic cotton? (Check ONE of the following)

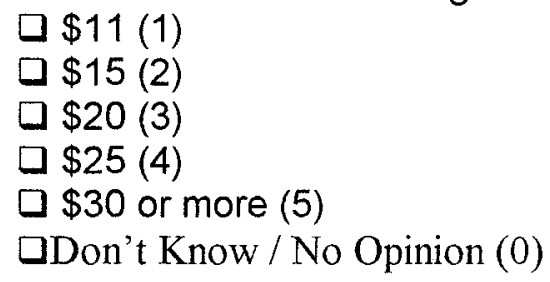

3. In the past 3 months, approximately how often have you purchased organic food or/ and vegetables?

$\square$ Never (0)

$\square$ Less than once per month (1)

$\square$ Between once to 3 times per month (2)

$\checkmark 4$ or more times per month (3)

aEvery time I shop, I buy organic (4)

4. Over the past 6 months, have you purchased clothing made with organic cotton as a gift or for yourself?

$\square$ YES (1)

$\square$ NO (0)

4 (a). In your opinion, what are the 2 MOST IMPORTANT reasons for you to purchase organic cotton clothing?

$\square$ Environmental benefits (1)

$\square$ Lower pesticide residue (product safety) (2)

$\square$ Safer working conditions (3)

Good product quality (4)

$\square$ Right price (5)

4 (b). Based on your experience and understanding, what reasons explain why you do not buy organic cotton clothing? (Check all that apply)

Do not know or ever hear anything about organic cotton (1)

$\checkmark$ Cannot find stores selling organic cotton products (2)

$\square$ It is usually too expensive (3)

$\checkmark$ Clothing made with organic cotton does not come in enough styles or types of products (4)

$\square$ Do not see any direct benefits of buying it (5)

$\square$ It has bad product quality (6) 


\section{Attitudes}

Which of the following responses best describes your attitudes about the following statements:

7. If things continue on their present course, we will soon experience a major ecological disaster.
口Strongly
口Disagree
Deutral
$\square$ Agree
口Strongly
Disagree
$(-2)$
$(-1)$
(0)
(1)
(2)

8. I am willing to cut my current living standard to protect the environment.
口Strongly
$\square$ Disagree
$\square$ Neutral
$\square$ Agree
aStrongly
Disagree
$(-1)$
$(0)$
(1)
Agree
(2)

$(-2)$

9. Current claims that environmental problems are changing the earth's climate are exaggerated.
口Strongly
aDisagree
$\square$ Neutral
$\square$ Agree
Disagree
$\square$ Strongly
Agree

(2)

(1)

$(0)$

(1)

(2)

10. The consumer has the power to force products that pollute the environment off the market.
$\square$ Strongly
$\square$ Disagre
$\square$ Neutral
Disagree
$(-2)$
$(-1)$
(0)
$\square$ Agree
$\square$ Strongly
Agree
(2)
(1)

11. All things considered, organic foods are no different than conventional foods.
口Strongly
Disagree
DDisagree
$\square$ Neutral
$\square$ Agree
$\square$ Strongly
Agree

(0)

(2)

(1)

(1)

(2)

12. People should buy environmentally- friendly products, even though they are sometimes more expensive.
DStrongly
口Disagree
$\square$ Neutral
$\square$ Agree
Disagree
$(-2)$
$(-1)$
(0)
(1)
$\square$ Strongly
Agree
(2)

Demographics

1. Your Gender

aMale (1) aFemale (2) 


\section{Your Age}

$(0-17=1 ; 18-29=2 ; 30-39=3 ; 40-49=4 ; 50-59=5 ; 60-69=6 ; 70$ and above=7)

3. Highest Education Level Completed

$\square$ Less than high school (1) aHigh school (2) 口Associate/ Junior College (3)

$\square$ Bachelor (4) $\square$ Graduate and above (5)

4. Your MONTHLY Personal Income

$\square \$ 0-2000(1) \quad \square \$ 2,001-3,000(2) \quad \square \$ 3,001-4,000(3)$

$\square \$ 4,001-5,000(4) \quad \square \$ 5,000$ and above (5)

5. What is your ethnicity? (Check all that apply)

$\square$ White (1)

Black or African American (2)

a Spanish/Hispanic/Latino (3)

- Asian or Pacific Islander (4)

American Indian or Alaskan Native (5)

口 Other (6) 